OPEN ACCESS

Edited by:

Laura Santambrogio,

Weill Cornell Medicine, Cornell

University, United States

Reviewed by:

Scheherazade Sadegh-Nasseri,

Johns Hopkins University,

United States

Daniel M. Altmann,

Imperial College London,

United Kingdom

${ }^{*}$ Correspondence:

Richard Weiss

richard.weiss@sbg.ac.at

Specialty section

This article was submitted to

Antigen Presenting Cell Biology,

a section of the journal

Frontiers in Immunology

Received: 11 March 2020

Accepted: 07 July 2020

Published: 18 August 2020

Citation:

Winter P, Stubenvoll S, Scheib/hofer S, Joubert IA, Strasser L, Briganser C,

Soh WT, Hofer F, Kamenik AS, Dietrich V, Michelini S, Laimer J,

Lackner P, Horejs-Hoeck J,

Tollinger M, Liedl KR, Brandstetter J, Huber CG and Weiss R (2020) In silico

Design of Phl $p 6$ Variants With Altered

Fold-Stability Significantly Impacts

Antigen Processing, Immunogenicity

and Immune Polarization.

Front. Immunol. 11:1824.

doi: 10.3389/fimmu.2020.01824

\section{In silico Design of Phl p 6 Variants With Altered Fold-Stability Significantly Impacts Antigen Processing, Immunogenicity and Immune Polarization}

\author{
Petra Winter ${ }^{1}$, Stefan Stubenvoll ${ }^{1}$, Sandra Scheiblhofer ${ }^{1}$, Isabella A. Joubert ${ }^{1}$, \\ Lisa Strasser ${ }^{1}$, Carolin Briganser ${ }^{1}$, Wai Tuck Soh ${ }^{1}$, Florian Hofer ${ }^{2}$, Anna Sophia Kamenik ${ }^{2}$, \\ Valentin Dietrich ${ }^{3}$, Sara Michelini ${ }^{1}$, Josef Laimer ${ }^{1}$, Peter Lackner ${ }^{1}$, Jutta Horejs-Hoeck ${ }^{1}$, \\ Martin Tollinger ${ }^{3}$, Klaus R. LiedI ${ }^{2}$, Johann Brandstetter ${ }^{1}$, Christian G. Huber ${ }^{1}$ and \\ Richard Weiss ${ }^{1 *}$
}

${ }^{1}$ Department of Biosciences, University of Salzburg, Salzburg, Austria, ${ }^{2}$ Center of Molecular Biosciences \& Institute of General, Inorganic and Theoretical Chemistry, University of Innsbruck, Innsbruck, Austria, ${ }^{3}$ Center of Molecular Biosciences \& Institute of Organic Chemistry, University of Innsbruck, Innsbruck, Austria

Introduction: Understanding, which factors determine the immunogenicity and immune polarizing properties of proteins, is an important prerequisite for designing better vaccines and immunotherapeutics. While extrinsic immune modulatory factors such as pathogen associated molecular patterns are well-understood, far less is known about the contribution of protein inherent features. Protein fold-stability represents such an intrinsic feature contributing to immunogenicity and immune polarization by influencing the amount of peptide-MHC II complexes (pMHCII). Here, we investigated how modulation of the fold-stability of the grass pollen allergen Phl p 6 affects its ability to stimulate immune responses and $T$ cell polarization.

Methods: MAESTRO software was used for in silico prediction of stabilizing or destabilizing point mutations. Mutated proteins were expressed in E. coli, and their thermal stability and resistance to endolysosomal proteases was determined. Resulting peptides were analyzed by mass spectrometry. The structure of the most stable mutant protein was assessed by X-ray crystallography. We evaluated the capacity of the mutants to stimulate $T$ cell proliferation in vitro, as well as antibody responses and $T$ cell polarization in vivo in an adjuvant-free BALB/c mouse model.

Results: In comparison to wild-type protein, stabilized or destabilized mutants displayed changes in thermal stability ranging from -5 to $+14^{\circ}$. While highly stabilized mutants were degraded very slowly, destabilization led to faster proteolytic processing in vitro. This was confirmed in BMDCs, which processed and presented the immunodominant epitope from a destabilized mutant more efficiently compared to a highly stable mutant. In vivo, stabilization resulted in a shift in immune polarization from $\mathrm{TH} 2$ to $\mathrm{TH} 1 / \mathrm{TH} 17$ as indicated by higher levels of IgG2a and increased secretion of TNF- $\alpha$, IFN- $\gamma, \mathrm{IL}-17$, and IL-21. 
Conclusion: MAESTRO software was very efficient in detecting single point mutations that increase or reduce fold-stability. Thermal stability correlated well with the speed of proteolytic degradation and presentation of peptides on the surface of dendritic cells in vitro. This change in processing kinetics significantly influenced the polarization of $T$ cell responses in vivo. Modulating the fold-stability of proteins thus has the potential to optimize and polarize immune responses, which opens the door to more efficient design of molecular vaccines.

Keywords: structural stability, endolysosomal degradation, antigen processing and presentation, protein stabilization, immune polarization, in silico mutagenesis, in silico mutant screening

\section{INTRODUCTION}

An important question for the design and understanding of molecular vaccines is how protein intrinsic factors determine the immunogenic properties of an antigen. Several parameters have been identified that can have a strong impact on the immunogenicity and immune polarizing potential of allergens, like aggregation behavior (1), glycosylation (2), molecular mimicry (3), or enzymatic activity (4). However, one of the most important underlying principles is that for a strong immune response sufficient amounts of peptides have to be presented on major histocompatibility complex molecules to provide optimal stimulation for $\mathrm{T}$ cells (5). Moreover, the amount of peptideMHC complexes (pMHC) on the surface of antigen presenting cells (APCs) can influence the polarization of naïve Thelper (TH) cells. While in the classic qualitative model, TH cell polarization is mainly determined by cytokines secreted by APCs, there is growing evidence for an important role of strength and duration of the pMHCII-T cell receptor (TCR) interaction. In favor of the quantitative model, it has been consistently shown in vitro that low antigen doses promote $\mathrm{TH} 2$ polarization, while high antigen doses induce IFN- $\gamma$ secreting TH1 cells $(6,7)$. More recently, van Panhuys et al. have shown for the first time in vivo that the quantity of antigen presented by a dendritic cell (DC) may overrule qualitative signals provided by the same DC, thus shifting $\mathrm{T}$ cell polarization from either TH1 to $\mathrm{TH} 2$ or vice versa (8). Consequently, a model emerges, where depending on the pMHCII-TCR interaction, a DC can induce no response, anergy, TH2 polarization, TH1 polarization, or activation induced cell death with increasing signal strength (9). Moreover, it has been shown that TCR signaling strength is also crucial for the induction of Th polarization (10-12), persistence of Foxp $3^{+}$Tregs $(13,14)$, and differentiation of TH17 effector cells (15). These findings have important implications for the design of novel vaccines, and for our understanding why some proteins are potent TH2 inducers (allergens), while other proteins induce TH1 responses [e.g., viral proteins (16)].

Based on this concept, the overall fold-stability of an antigen has been suggested as an important protein intrinsic parameter that can influence immunogenicity and immune polarization. Proteins with a high conformational stability are on the one hand more resistant to proteases, which are abundant on skin, mucosal surfaces and in the extracellular matrix $(17,18)$, and on the other hand also frequently display enhanced resistance against proteolytic digestion in the endolysosomal compartment of APCs. Hence, fold-stability substantially controls the cell surface density of pMHCII molecules specific for a given antigen, thereby influencing the immune polarization of $\mathrm{T}$ cells. Moreover, hyperstable proteins, which resist proteolysis within the antigen processing compartment, may escape into the cytoplasm of APCs and enter the cross-presentation pathway through the proteasome. The resulting peptides finally end up on MHC I and are presented to CD8 T cells. Several studies supporting these ideas were reviewed by Scheiblhofer et al. (19). However, the results described are inconsistent, as different methods were used to modulate protein stability and different experimental settings were applied.

Various methods have been used to manipulate the conformational stability of a protein such as the introduction of cysteine bonds $(20,21)$, pairing of charges (22), or chemical cross linking $(23,24)$. However, the outcome of such mutations and the immunological effects of chemical cross linkers are often difficult to predict. In our current work we therefore employed an in silico mutagenesis approach using MAESTRO (25), a software tool, which predicts the effect of point mutations on the free energy $(\Delta \Delta \mathrm{G})$ of the molecule. We used the grass pollen allergen Phl p 6, which is a small globular protein of $11.8 \mathrm{kD}$ that can be easily expressed in E. coli and is a known inducer of TH2 responses. We selected single point mutations that either stabilized or destabilized Phl p 6 without changing immunodominant $\mathrm{T}$ cell epitopes or the overall structure of the protein. Using these mutant proteins, we investigated the effect of fold-stability on antigen processing and presentation, as well as on immunogenicity and immune polarization in vitro and in vivo.

\section{MATERIALS AND METHODS}

\section{In silico Mutagenesis}

Stabilizing or destabilizing mutations were selected in silico using the MAESTRO software tool (25) for predicting the influence of single point mutations or combinations thereof on protein stability. The change in stability predictions are based on the PDB entry 1NLX chain L. The structurally unresolved residues at the $\mathrm{N}$ - and C-terminus were modeled using the UCSF Chimera (26) interface to MODELER (27). The final model was subjected to a MAESTRO greedy search, excluding the 
major T cell epitopes 65-79 (DEVYNAAYNAADHAA) and 92106 (SEALRIIAGTPEVHA). Mutations with a relative accessible surface area or of $<30 \%$ were defined as buried residues and $>30 \%$ as surface exposed residues.

\section{Expression and Purification of Recombinant Proteins}

Wild-type Phl p 6 and its mutants were expressed from pET17b constructs in Escherichia coli strain BL21 Star (DE3; Invitrogen/Thermo Fisher Scientific). Cells were grown in autoinducing ZYM 5052 medium (28) supplemented with $100 \mathrm{mg} / \mathrm{L}$ ampicillin in baffled flasks at $37^{\circ} \mathrm{C}$ for $20 \mathrm{~h}$. Cells were lysed in $6 \mathrm{~mL}$ lysis buffer ( $25 \mathrm{mM}$ imidazole, $0.5 \mathrm{mM}$ EDTA, $\mathrm{pH} 7.4$ ) per gram pellet weight and $300 \mu \mathrm{g} / \mathrm{mL}$ lysozyme was added. After stirring for $30 \mathrm{~min}$ at RT, bacterial cells were lysed by three freeze/thaw cycles at $70^{\circ} \mathrm{C}$. DNA was digested by addition of $100 \mu \mathrm{g}$ DNAse I (Roche) per gram pellet weight and stirring at RT for $60 \mathrm{~min}$. After centrifugation $(20,000 \mathrm{~g}, 45 \mathrm{~min}$, $5^{\circ} \mathrm{C}$ ), unwanted proteins were removed from the supernatant by $30 \%$ ammonium sulfate precipitation. The supernatant was further purified using hydrophobic interaction chromatography (Phenylsepharose 6, fast flow, GE Healthcare) using $25 \mathrm{mM}$ imidazole, $1.25 \mathrm{M}$ ammonium sulfate, $\mathrm{pH} 7.5$ as binding buffer and $25 \mathrm{mM}$ imidazole $\mathrm{pH} 7.4$ for the elution gradient. Fractions were analyzed on a $15 \%$ acrylamide gel by SDS PAGE and Phl p 6 containing fractions were pooled and dialyzed three times against $25 \mathrm{mM}$ imidazole, 4\% 2-propanol, pH 7.4. Dialyzed pooled fractions were applied to anion exchange chromatography (DEAE sepharose fast flow, GE Healthcare) using $20 \mathrm{mM}$ imidazole, 4\% 2-propanol, pH 7.4 for equilibration and washing. Elution was performed with a $\mathrm{NaCl}$ gradient in the same buffer. Fractions containing Phl p 6 were finally purified by size exclusion chromatography using a 100/60 sephacryl S200HR (GE Healthcare) column equilibrated with $2 \mathrm{mM}$ sodium phosphate buffer, $\mathrm{pH} 7.4$.

${ }^{15} \mathrm{~N}$ and ${ }^{15} \mathrm{~N} /{ }^{13} \mathrm{C}$ labeled protein samples for $\mathrm{NMR}$ spectroscopy were recombinantly produced using M9 minimal media supplemented with ${ }^{15} \mathrm{NH}_{4} \mathrm{Cl}$ and ${ }^{13} \mathrm{C}$-D-glucose and purified as described above.

Endotoxin content was determined by Limulus amebocyte assay (PYROTELL ${ }^{\circledR}-\mathrm{T}$, Associates of Cape Cod, MA, USA) according to the manufacturer's instructions. Selected proteins were also tested for masked endotoxin using a NFкB reporter assay based on HEK293 cells overexpressing TLR4, MD-2, and CD14, as previously described $(29,30)$.

\section{HPLC-MS Analysis}

Purified proteins were analyzed by high-performance liquid chromatography-mass spectrometry (HPLC-MS) using a Q Exactive $^{\mathrm{TM}}$ Hybrid Quadrupole-Orbitrap ${ }^{\mathrm{TM}}$ mass spectrometer (Thermo Fisher Scientific) online hyphenated to an UltiMate ${ }^{\mathrm{TM}}$ RSLC nano system (Thermo Fisher Scientific) by means of a nano-electrospray ionization source. Prior to analysis, samples were purified using Pierce ${ }^{\mathrm{TM}} \mathrm{C} 18$ tips (Thermo Fisher Scientific) as described in the manufacturer's manual.

Two hundred and fifty nanogram of the respective protein were injected onto a Waters X Bridge Protein BEH C4 $2.1 \times$
$150 \mathrm{~mm}$ column with $3.5 \mu \mathrm{m}$ particles and a pore size of 300 $\AA$ (Waters, Milford, MA, USA). Water (A) and acetonitrile (B; Sigma Aldrich) each containing $0.10 \%(\mathrm{v} / \mathrm{v})$ formic acid (FA) were used as eluents. At a flow rate of $200 \mu \mathrm{L} / \mathrm{min}$ proteins were eluted by applying a linear gradient of $20.0-60.0 \%$ B over $3 \mathrm{~min}$. The column temperature was set to $60^{\circ} \mathrm{C}$. The mass spectrometer was operated in positive ionization mode. Full scans were performed at a scan range of $\mathrm{m} / \mathrm{z} 500-1,500$ at a resolution of $140,000($ at $\mathrm{m} / \mathrm{z}=200)$. The AGC-target was set to $1 \times 10^{6}$ with a maximum injection time (IT) of $100 \mathrm{~ms}$.

For data analysis, Xcalibur 3.0 (Thermo Fisher Scientific), Proteome Discoverer 1.4 (Thermo Fisher Scientific), and GPMAW (Lighthouse data, Denmark) were used.

\section{Molecular Dynamics and Protein Flexibility}

We performed molecular dynamics simulations of wild-type Phl p 6 and the four in silico selected mutants to profile the respective conformational ensembles and intrinsic flexibilities. In order to achieve broad conformational sampling, we used accelerated molecular dynamics simulations (aMD). For the wild-type, the starting structure for the simulation was obtained from the available crystal structure 1NLX. We note that in this structure, only 104 of the total 111 residues of the allergen are resolved. In detail, four C-terminal residues as well as three $\mathrm{N}$ terminal residues (including the starting methionine) are not resolved. For the mutants, starting structures were modeled based on the wild-type structure. The respective point mutations were introduced with the program MOE (molecular operating environment, Chemical Computing Group, Montreal, Canada), followed by local minimization. Structures were protonated at $\mathrm{pH}$ 7.0 with the tool protonate $3 \mathrm{~d}$ as implemented in MOE. Topology and starting coordinate files were generated with the LEaP module of AmberTools 17 (31) using the ff99SB-ILDN force field (32). Each protein was placed in a truncated octahedral TIP3P water box (33) with a minimum wall distance of $10 \AA$ A. After an elaborate equilibration protocol, consisting of subsequent relaxing, heating and cooling steps (34) short conventional molecular dynamics simulations of $100 \mathrm{~ns}$ length were performed to obtain acceleration parameters (35). Subsequent accelerated MD simulations were performed for 1,000 ns per system. Simulations were carried out in the NpT ensemble, using a Langevin thermostat $\mathrm{t}(36)$ with a collision frequency of $2 \mathrm{ps}^{-1}$ to keep a constant temperature of $310 \mathrm{~K}$, as well as a Berendsen barostat (37) with a relaxation time of 2 ps to keep the system at atmospheric pressure. Bonds involving hydrogen bonds were constrained with the SHAKE algorithm to allow the use of $2 \mathrm{fs}$ time (38). A van der Waals cutoff of $10 \AA$ was used and longrange electrostatics were treated with the particle-mesh Ewald method (PME) (39). All simulations were carried out with the GPU acceleration of the pmemd module of AMBER 17 on our in-house cluster. Snapshots were saved each $10 \mathrm{ps}$.

All trajectories were reweighted with a McLaurin series to the 10th order prior to analysis $(35,40)$. Analyses were carried out with the program cpptraj (41) of AmberTools 17 and in-house python scripts. Local flexibilities were characterized by calculating the dihedral entropies resulting from backbone torsion probability profiles (42). Structural visualizations were 
achieved by calculating the residues-wise differences in dihedral entropy for each system, using the wild-type as a reference and mapping the respective differences onto the respective crystal structures using the program PyMol (43).

\section{Protein Folding and Stability}

Protein folding in solution was monitored by circular dichroism spectroscopy using a JASCO J-815 spectropolarimeter equipped with a PTC-423S Peltier-type single position cell holder (Jasco). Proteins were dissolved to $10 \mu \mathrm{M}$ in $2 \mathrm{mM}$ sodium phosphate buffer pH 7.4 and spectra were recorded from 190 to $260 \mathrm{~nm}$. Thermal denaturation was monitored at $222 \mathrm{~nm}$ from 20 to $90^{\circ} \mathrm{C}$ with a temperature slope of $1^{\circ} \mathrm{C} / \mathrm{min}$.

All NMR measurements were carried out with $0.75 \mathrm{mM} \mathrm{Phl}$ p 6 in $10 \mathrm{mM}$ sodium phosphate buffer $\mathrm{pH} 7.0$ with $10 \% \mathrm{D}_{2} \mathrm{O}$. For protein assignment, standard triple-resonance methodology was employed. ${ }^{15} \mathrm{~N}$ HSQC spectra (44) of wild-type Phl p 6 and $\mathrm{L} 89 \mathrm{G}$ and E39L mutants were measured in a temperature range between 20 and $70^{\circ} \mathrm{C}$ in steps of $5^{\circ} \mathrm{C}$. Chemical shift changes due to the change in temperature were recorded using $500 \mu \mathrm{M}$ sodium trimethylsilylpropanesulfonate (TMS) as reference substance ( $0 \mathrm{ppm}$ at all temperatures).

\section{Protein Crystallization, Data Collection, and Structure Determination}

For initial crystallization screening, the sitting-drop vapordiffusion method was applied, utilizing a Hydra II Plus One (Matrix) liquid-handling system. $0.2 \mu \mathrm{L}$ Phl p 6 mutant proteins at a concentration of $10 \mathrm{mg} / \mathrm{mL}$ were mixed with $0.2 \mu \mathrm{L}$ screen solution from different commercial screens and equilibrated against $60 \mu \mathrm{L}$ reservoir solution in a 96-well-plate (Art Robbins Instruments) at $293 \mathrm{~K}$. Crystals were observed in condition consisting of $0.05 \mathrm{M}$ zinc acetate dehydrate, $20 \%(\mathrm{w} / \mathrm{v}$ ) polyethylene glycol (PEG) 3350 for Phl p 6 S46Y. Fine screening was carried out using different protein to drop ratio 1:1, 1:1.5, 1:2, PEG3350 concentration $10-25 \%$ in hanging drop at $293 \mathrm{~K}$. Phl p 6 S46Y mutant crystals were observed in condition consisting of $0.05 \mathrm{M}$ zinc acetate dehydrate, $10 \%$ (w/v) PEG3350 with a protein to drop ratio of 1:1. Micro-seeding using Phl p 6 S46Y crystals was performed to ease the crystallization of other mutants (45). The crystals were cryo-protected with $10 \%$ glycerol and flash frozen in liquid nitrogen. Diffraction datasets were collected at the ESRF beamline ID29 and processed using iMosflm (46) and Scala in the CCP4 software suite (47). The structure was solved by molecular replacement using the existing Phl p 6 structure (PDB: 1NLX). Molecular replacement was done using CCP4 software suite. Structure models were built using COOT (48) and refined using Phenix (49). Anomalous data sets were collected at the Zinc Kabsorption edge and data processing was performed as described above. The two data sets were then combined and scaled using Scaleit in the CCP4 software suite. The anomalous difference was calculated using Sftools in the CCP4 software suite. Finally, the anomalous difference Fourier maps were calculated with FFT in the CCP4 software suite. The coordinates of Phl p 6 S46Y have been deposited in the Protein Data Bank under the entry code 6TRK, see Supplementary Table 1 for crystallographic data and refinement statistics.

\section{Endolysosomal Degradation Assay}

Endolysosomal degradation assays were performed as previously described (50). Briefly, $5 \mu \mathrm{g}$ of protein substrates (Phl p $6 \mathrm{WT}$, and its variants N16M, E39L, S46Y, and L89G) were mixed with $7.5 \mu \mathrm{g}$ of isolated microsomal fraction from the JAWS II cell line in $50 \mathrm{mmol} / \mathrm{L}$ citrate buffer $(\mathrm{pH} \mathrm{5.2}$, or $\mathrm{pH} \mathrm{4.5)}$ and $2 \mathrm{mmol} / \mathrm{L}$ dithiothreitol. Samples were incubated at $37^{\circ} \mathrm{C}$ for the indicated time points followed by 5 min denaturation at $95^{\circ} \mathrm{C}$ to stop the reaction. Samples were analyzed on $20 \%$ acrylamide gels by SDSPAGE and coomassie staining followed by densitometric analysis of the full length protein using ImageJ. For Phl p 6 WT, S46Y, and L89G, the pool of generated peptides was additionally analyzed by HPLC-MS as described above for intact proteins. To identify individual peptides resulting from endolysosomal degradation, $600 \mathrm{ng}$ were injected onto a self-packed $200 \times 0.1 \mathrm{~mm}$ Hypersil GOLD $^{\text {TM }}$ aQ C18 (Thermo Fisher Scientific) capillary column with $3.0 \mu \mathrm{m}$ particles. Peptides were separated at a flow rate of $350 \mathrm{~nL} / \mathrm{min}$ using a linear gradient of $5.0-40.0 \% \mathrm{~B}$ in $60 \mathrm{~min}$ at $50^{\circ} \mathrm{C}$. For MS detection, survey scans were performed for a scan range of $\mathrm{m} / \mathrm{z} 370-2,000$ at a resolution of 70,000 (at $\mathrm{m} / \mathrm{z}=200$ ). The AGC target was set to $1 \times 10^{6}$ with a maximum IT of $120 \mathrm{~ms}$. The 15 most intense ions were selected for fragmentation using a normalized collision energy of 29. Data dependent MS2 scans were recorded at a resolution of 35,000 with an AGC target of 2 $\times 10^{5}$ and a maximum IT of $100 \mathrm{~ms}$.

\section{Animal Experiments}

Female 6- to 10-week-old BALB/c mice were obtained from Janvier (Le Genest-Saint-Isle, France) and maintained at the animal facility of the University of Salzburg in a specific pathogen-free environment according to local guidelines. Animal experiments were approved by the Austrian Ministry of Education, Science and Research (permit no. BMWF66.012/0013-WF/V/3b/2017).

For initial epitope mapping and generation of $\mathrm{T}$ cell hybridomas, mice were immunized with $5 \mu \mathrm{g}$ Phl p 6 adsorbed to alum (50\% v/v Alu-Gel-S, Serva) by s.c. injection of $200 \mu \mathrm{L}$ divided between two sites on the back. Immunizations were performed on days 0,19 , and 48 , and mice were sacrificed 1 week later.

To assess in vivo immunogenicity of the different proteins and for repeated epitope mapping, mice were immunized with $10 \mu \mathrm{g}$ of Phl p 6 or one of the mutant proteins in sterile PBS without adjuvant by means of intradermal injections at two sites on the shaved back $(2 \times 20 \mu \mathrm{L})$. Mice were immunized on days 0,14 , and 28. On day 44, mice received terminal anesthesia $(100 \mathrm{mg} / \mathrm{kg}$ Ketamine $+3 \mathrm{mg} / \mathrm{kg}$ Xylazine $+3 \mathrm{mg} / \mathrm{kg}$ Acepromazine) by i.p. injection and their blood was collected from retroorbital sinus.

\section{Lymphocyte Cultures and Cytokines}

Following terminal blood collection, mice were sacrificed by cervical dislocation. Spleens were aseptically removed and transferred into $40 \mathrm{~mm}$ Petri dishes containing $500 \mu \mathrm{L}$ DPBS. Spleens were homogenized using the back of a sterile plunger from a $2 \mathrm{~mL}$ syringe and the suspensions were transferred into $1.5 \mathrm{~mL}$ tubes. After 3-5 min incubation at room temperature (until debris had settled), the monodisperse cell suspension was 
transferred into a $15 \mathrm{~mL}$ tube, pre-filled with $7 \mathrm{~mL}$ of ACK red blood cell lysis buffer $\left(0.15 \mathrm{M} \mathrm{NH} \mathrm{NH}_{4}, 10 \mathrm{mM} \mathrm{KHCO}_{3}\right.$, $0.1 \mathrm{mM} \mathrm{NA} 2$ EDTA, $\mathrm{pH} \mathrm{7.2-7.4)}$ and incubated for $7 \mathrm{~min}$ at RT. Tubes were filled up with $6 \mathrm{~mL}$ of DPBS, centrifuged for $5 \mathrm{~min}$ at $260 \mathrm{~g}$ at RT, and the pellets were washed with $5 \mathrm{~mL}$ of DPBS. After centrifugation, the pellets were resuspended in $10 \mathrm{~mL}$ warm DPBS containing $1 \mu \mathrm{M}$ eFluor 450 cell proliferation dye (eBioscience/Thermo Fisher Scientific). After incubation for $10 \mathrm{~min}$ at $37^{\circ} \mathrm{C}$, labeling was stopped by addition of $10 \%$ FCS. After two washing steps with DPBS, lymphocytes were re-suspended in T-cell medium (RPMI, 10\% FCS, 25 mM HEPES, $2 \mathrm{mM}$ L-Glu, $100 \mu \mathrm{g} / \mathrm{mL}$ streptomycin, $100 \mathrm{U} / \mathrm{mL}$ penicillin) and counted using a CEDEX XS Cell Analyzer (Roche). $3 \times 10^{5}$ cells per well were incubated in U-bottom tissue culture plates with $20 \mu \mathrm{g} / \mathrm{mL} \mathrm{Phl} \mathrm{p} 6$ or the mutant proteins, or $10 \mu \mathrm{g} / \mathrm{mL}$ of individual peptides from a 15 mer library (GenScript, NJ, USA) with an offset of 3 amino acids in a total volume of 150 $\mu \mathrm{L}$ per well. After 4 days, culture supernatants were removed and cells were harvested for flow cytometric analysis. Cytokine levels in supernatants were analyzed using the LEGENDplex ${ }^{\mathrm{TM}}$ Mouse TH Cytokine Panel (13-plex, BioLegend) according to the manufacturer's instructions.

\section{Epitope Mapping}

Restimulated splenocytes were transferred to V-bottom plates and stained in DPBS for $10 \mathrm{~min}$ at RT with fixable viability dye eFluor 780 (1:5,000, eBioscience) and anti-mouse CD4 PerCp/Cy5.5 (1:200, BioLegend, SanDiego, USA, clone GK1.5) and finally analyzed on a Cytoflex S flow cytometer (Beckmann Coulter). Proliferating cells among live CD4+ T cells were identified by their reduced fluorescence on the eFluor 450 channel. Peptides were considered immunoreactive if the stimulation index (\% proliferating cells stimulated with peptide $/ \%$ proliferating cells without stimulation) was $>2$.

\section{Antibody Measurements}

To determine the production of Phl p 6-specific serum IgG1 and IgG2a, a luminometric ELISA was performed at serum dilutions lying within the linear range of the assay. 96-well plates (flat white chimney; Greiner) were coated with $1 \mu \mathrm{g} / \mathrm{mL}$ recombinant $\mathrm{Phl} \mathrm{p} 6$ or the mutant proteins diluted in PBS (50 $\mu \mathrm{L}$ per well) overnight at $4^{\circ} \mathrm{C}$. The coating solution was discarded and $200 \mu \mathrm{L}$ of blocking buffer (2\% skim milk, blotting grade, and $0.1 \%$ Tween ${ }^{\circledR}-20$ in PBS) were added to each well and incubated for $1 \mathrm{~h}$ at RT. The plate was washed with PBS-T (PBS, 0.1\% Tween-20) using an automated plate washer (Tecan 96PW Microplate Washer). Meanwhile, serum dilutions (1:100 for IgG2a and 1:100,000 for IgG1) were prepared in blocking buffer. Fifty microliter of each serum dilution was added to the wells and incubated for $2 \mathrm{~h}$ at $37^{\circ} \mathrm{C}$ in a humid chamber. After another washing step, $50 \mu \mathrm{L}$ of the secondary antibody (goat anti-mouse IgG1-HRP diluted 1:1,000, Bio-Rad; rabbit anti-mouse IgG2a-HRP diluted 1:2,000, antibodies-online.com) were added in blocking buffer. The plate was incubated for $1 \mathrm{~h}$ at RT. After a final washing step, $50 \mu \mathrm{L}$ of an ELISA BM chemiluminescence substrate (Roche) was added and after 2$3 \mathrm{~min}$ the luminescence was measured in relative light units
(RLU) using a plate reader (Tecan inifinite 200Pro; integration time of 1,000 ms and attenuation set to automatic).

For assessment of biologically active, specific IgE in sera, a $\beta$-hexosaminidase release assay was performed. Briefly, rat basophil leukemia (RBL-2H3) cells were seeded in 96-well tissue culture plates and incubated overnight at $37^{\circ} \mathrm{C}, 5 \% \mathrm{CO}_{2}, 95 \%$ humidity. The next day, sera were added for passive sensitization at indicated dilutions. Background wells and wells for maximum release remained untreated. After $2 \mathrm{~h}$ of incubation, cells were washed three times with Tyrode's buffer containing $0.1 \%$ BSA and incubated for $1 \mathrm{~h}$ with $10 \mathrm{ng} / \mathrm{mL}$ of Phl p 6 or the mutant proteins in Tyrode's buffer for stimulation. Ten microliter of a $10 \%$ Triton X-100 was added to some wells for maximum release. Supernatants containing released mediators including $\beta$-hexosaminidase were transferred to fresh plates and assay solution (4-MUG diluted in $0.1 \mathrm{M}$ citrate buffer, $\mathrm{pH} 4.5$ ) was added for $1 \mathrm{~h}$. The reaction was stopped by addition of $100 \mu \mathrm{L}$ glycine buffer ( $0.2 \mathrm{M}$ glycine, $0.2 \mathrm{M} \mathrm{NaCl}, \mathrm{pH} 10.7)$. Fluorescence intensity was measured on a TECAN plate reader at $\lambda_{\text {ex }}: 360 \mathrm{~nm}$ and $\lambda_{\mathrm{em}}: 465 \mathrm{~nm}$. Percentage of specific lysis was calculated by the formula $\left(\mathrm{rfu}-\mathrm{rfu}_{\mathrm{back}}\right) /\left(\mathrm{rfu}_{\max }-\mathrm{rfu}_{\mathrm{back}}\right)^{*} 100$.

Cell-bound IgE was measured ex vivo using a basophil activation test (BAT). On the day of sacrifice, blood was taken from the retro orbital sinus and mixed with $1 / 10$ vol. of LiHeparin $(1.5 \mathrm{mg} / \mathrm{mL}$ in DPBS) to prevent coagulation. Thirty microliter of these blood samples were mixed with $30 \mu \mathrm{L}$ of RPMI with an equimolar mix of Phl p 6 WT, L89G, and S46Y and incubated for $2 \mathrm{~h}$ at $37^{\circ} \mathrm{C}, 5 \% \mathrm{CO}_{2}, 95 \%$ humidity. Final concentration of Phl p 6 in stimulated wells was $10 \mathrm{ng} / \mathrm{mL}$. After $2 \mathrm{~h}$, stimulation was stopped by putting the plates on ice, and all subsequent steps were performed with ice-cold solutions and samples were kept on ice. Samples were washed with 120 $\mu \mathrm{L}$ FACS buffer (PBS, 1\% BSA, 2 mM EDTA) and cell pellets ( $5 \mathrm{~min}$ centrifugation at $260 \mathrm{~g}$ ) were resuspended in $30 \mu \mathrm{L}$ of FACS buffer containing anti-IgE-FITC (BioLegend, clone RME1, 1:200), anti-CD4-PerCp-Cy5.5 (BioLegend, clone GK1.5, 1:200), anti-CD19-PE/Cy7 (BioLegend, clone 6D5, 1:200), and anti-CD200R-APC (eBioscience/Thermo Fisher Scientific, clone OX110, 1:200). Samples were stained for $20 \mathrm{~min}$ on ice and washed with $100 \mu \mathrm{L}$ FACS buffer. After 5 min centrifugation at $260 \mathrm{~g}$, pellets were resuspended in $150 \mu \mathrm{L}$ red blood cell lysis buffer (eBioscience/Thermo Fisher Scientific) and incubated for $5 \mathrm{~min}$ at RT. Cells were centrifuged for $5 \mathrm{~min}$ at $400 \mathrm{~g}$ and pellets were washed two times with FACS buffer. Finally, cell pellets were resuspended in $50 \mu \mathrm{L}$ FACS buffer and analyzed on a FACS Canto II flow cytometer (BD Biosciences). Basophils were gated as IgE ${ }^{\text {high }} \mathrm{CD} 19^{\text {neg }} \mathrm{CD} 4^{\text {neg }}$ cells and activation status was assessed by the median fluorescence intensity of CD200R as previously described (51).

\section{Generation of BMDCs and Phl p 6-Specific T Cell Hybridomas}

For generation of bone marrow-derived dendritic cells (BMDCs), bone marrow was harvested from femur and tibia of BALB/c mice. Ten milliliter of a $2 \times 10^{5}$ cells $/ \mathrm{mL}$ bone marrow cell suspension were plated into non-cell culture treated petri 
dishes and incubated in the presence of murine GM-CSF (Immunotools, Germany) for 6-8 days. On day 3, $10 \mathrm{~mL}$ of GM-CSF containing culture medium (RPMI1640 supplemented with $20 \mathrm{ng} / \mathrm{mL}$ GM-CSF, $100 \mathrm{U} / \mathrm{mL}$ penicillin, $100 \mu \mathrm{g} / \mathrm{mL}$ streptomycin, $2 \mathrm{mM}$ L-Glutamine, $10 \%$ FCS and $50 \mu \mathrm{M} 2$ mercaptoethanol) was added to each well, and on day $5,10 \mathrm{~mL}$ medium was replaced.

To generate Phl p 6-specific T cell hybridomas, splenocytes from Phl p 6 immunized mice were cultured in OptiMEM + GlutaMAX (Gibco), 5\% FCS, $100 \mathrm{U} / \mathrm{mL}$ penicillin, $100 \mu \mathrm{g} / \mathrm{mL}$ streptomycin, with the immunodominant peptide 31 (AA 92-106) at a final concentration of $3 \mu \mathrm{g} / \mathrm{mL}$. One week later, dead cells and peptides were removed by ficoll density gradient centrifugation and cells were incubated with $20 \mathrm{U} / \mathrm{mL}$ recombinant human IL-2 for another week. After removal of IL2 by washing, $T$ cells were co-cultured with syngeneic irradiated feeder cells (splenocytes from naïve BALB/c mice) with $6 \mu \mathrm{g} / \mathrm{mL}$ of the peptide for 8 days. On day 8 , T cells were harvested and fused with mouse thymus lymphoma cell line BW5147.G.1.4 (ATCC) according to standard protocols for generation of $\mathrm{T}$ cell hybridomas (52).

\section{Processing of Phl p 6 and Phl p 6 Mutants by BMDCs and Stimulation of Phl p 6-Specific T Cells}

Bone marrow-derived dendritic cells, generated by culturing bone marrow cells in the presence of GM-CSF, were incubated in 96-well U-bottom plates for $16-64 \mathrm{~h}$ in the presence of $20 \mu \mathrm{g} / \mathrm{mL}$ Phl p 6 WT, S46Y, or L89G in GM-CSF containing culture medium (RPMI1640 supplemented with $20 \mathrm{ng} / \mathrm{mL}$ GM-CSF, 100 $\mathrm{U} / \mathrm{mL}$ penicillin, $100 \mu \mathrm{g} / \mathrm{mL}$ streptomycin, $2 \mathrm{mM}$ L-Glutamine, $10 \%$ FCS and $50 \mu \mathrm{M} 2$-mercaptoethanol) in triplicates. Control wells received medium alone. After washing the cells 2 times with DPBS, $4 \times 10^{5} \mathrm{Phl}$ p 6 -specific T cell hybridoma cells were added in DMEM, $4 \mathrm{mM}$ L-Glu, 10\% FCS and co-cultured with proteinloaded BMDCs for another $24 \mathrm{~h}$. Standard wells contained BMDCs that were pulsed with different concentrations of peptide 92-106 during the $24 \mathrm{~h}$ of co-culture. Culture supernatants were removed and analyzed for IL-2 production as a correlate for $\mathrm{T}$ cell activation using an ELISA MAX mouse IL-2 set (BioLegend). IL-2 values measured in supernatants from the wells containing BMDCs pulsed with proteins for different time periods were transformed into $\mu \mathrm{M}$ peptide equivalents by interpolating in a standard curve generated from the values obtained from hybridomas co-cultured with BMDCs at indicated peptide concentrations.

\section{Statistics}

Statistical differences between groups were analyzed by oneway ANOVA followed by Tukey's post-hoc test unless otherwise indicated (Prism 7, GraphPad Software). Data are expressed as means \pm SEM $\left(P\right.$-value range is indicated: ${ }^{*} P<0.05$, ${ }^{* *} P<0.01$, *** $P<0.001$, and $\left.{ }^{* * * *} P<0.0001\right)$.

\section{RESULTS}

\section{Identification of Dominant T Cell Epitopes of Phl p 6}

To be able to exclude relevant $\mathrm{T}$ cell epitopes from the mutation process, the dominant T cell epitopes of Phl p 6 were identified by culturing splenocytes from Phl p 6-immunized mice together with 33 overlapping peptides covering its entire sequence (15mers, 3AA overlap). By determining the proliferation rate of CD4+ T cells, two major (peptides 22 and 31) and one minor (peptide 28) T cell epitopes were found (Figure 1). Sequences of the respective $\mathrm{T}$ cell epitopes are shown in Table $\mathbf{1}$.

\section{In silico Mutagenesis of Phl p 6}

In an unbiased approach, stabilizing and destabilizing single point mutations were calculated using the MAESTRO stability prediction software (25). The dominant T cell epitopes (6579 and 92-106, Figure 1 and Table 1) were excluded from the mutation process and the candidates were ranked by predicted changes in free energy ( $\Delta \Delta \mathrm{G}$ values, Tables 2,3$)$. We found surface exposed as well as buried amino acid exchanges among the top 10 stabilizing mutations, and chose two of each for further analysis (N16M, D52L, E39L, S46Y). On the contrary, the top 10 predicted mutations with destabilizing effect all targeted buried residues, primarily exchanging hydrophobic amino acids within the protein core, potentially leading to complete unfolding as indicated by the high $\Delta \Delta \mathrm{G}$ values. Furthermore, the number one candidate mutation was located close to an immunodominant $\mathrm{T}$ cell epitope, potentially altering a proteolytic cleavage site and thus abolishing its processing and presentation. Therefore, we selected the mutant ranked second (L64G) and performed another scan restricted to surface exposed residues, resulting in more moderate $\Delta \Delta G$ values. Here, the top two proposed mutations were exchanges to prolines within the alpha helical structure of $\mathrm{Phl} \mathrm{p}$ 6. As prolines are helix breakers, these mutations would dramatically alter the overall 3D structure of the mutant. Thus, we chose mutant L89G (ranked third) for expression and characterization.

\section{Expression and Characterization of Phl p 6 and Its Variants}

Proteins were expressed tag-free in E. coli with the exception of mutant L64G, which we were unable to produce, most likely due to its high degree of destabilization, impeding proper folding. Subsequently, proteins were purified by hydrophobic interaction chromatography followed by anion exchange chromatography and finally by size exclusion chromatography. The final purity was determined by SDS-PAGE using a $15 \%$ acrylamide gel and Coomassie staining (Figure 2A). After endotoxin removal, all preparations contained $<1$ pg LPS per $\mu$ g of protein according to Limulus amebocyte lysate assay. Proteins used for immunization of mice were additionally tested for masked LPS in a cellbased NF- $\kappa$ B-luciferase reporter gene assay using HEK293 cells overexpressing the LPS receptor subunits TLR4, CD14, and MD2. LPS content in Phl p $6 \mathrm{WT}$ and the mutant S46Y were below the detection limit of $0.0025 \mathrm{pg} / \mu \mathrm{g}$ protein; the L89G preparation contained $<0.1 \mathrm{pg} / \mu \mathrm{g}$. To confirm the correct amino 
A

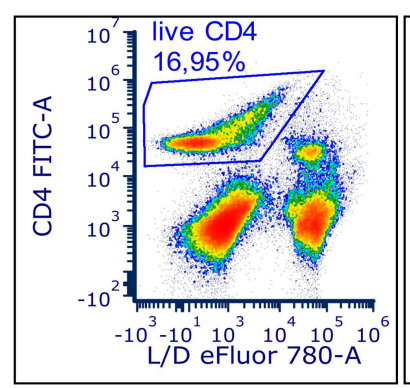

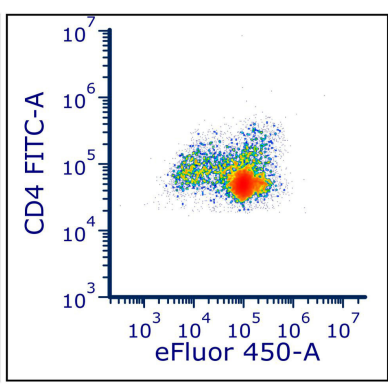

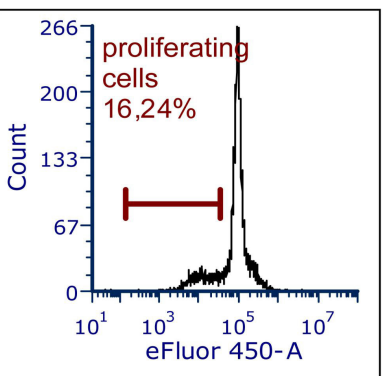

B

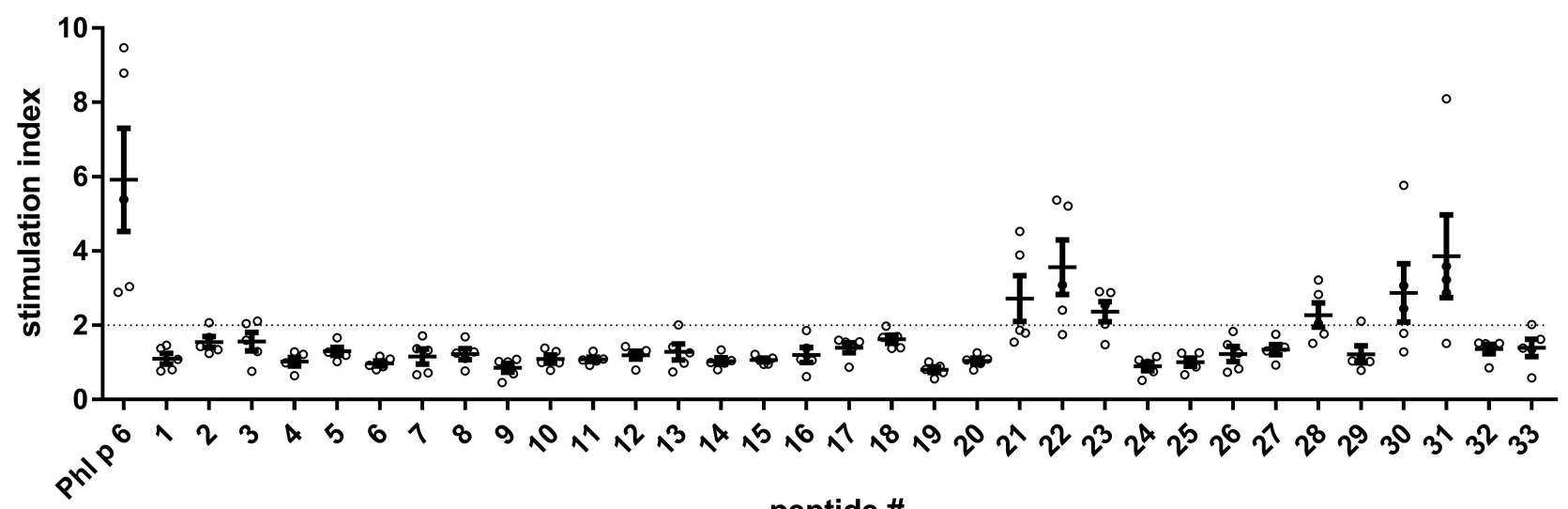

C

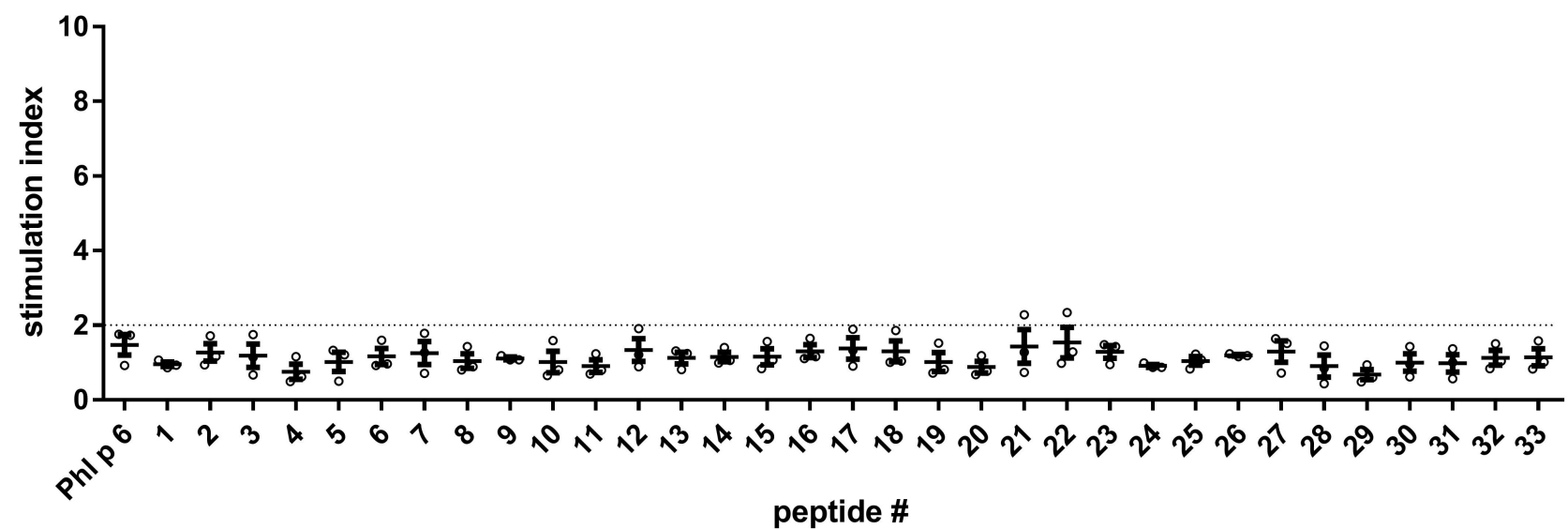

FIGURE 1 | BALB/c mice immunized with Phl p 6 display two immunodominant T cell epitope regions. Splenocytes from Phl p 6-immunized or naïve control mice were stained with eFluor 450 proliferation dye and restimulated for 3 days in vitro with Phl p 6 or 33 individual peptides covering its entire sequence (15mer with $3 A A$ overlap). Control samples were stimulated with medium alone. Proliferation of splenocytes was determined by flow cytometry. Live CD4 cells were gated followed by exclusion of doublets. Proliferating T cells were identified by their reduced levels of eFluor 450 dye (A). Data from Phl p 6-immunized (B) or naïve control mice (C) are shown as stimulation index (\% proliferation peptide/\% proliferation medium). A stimulation index above 2 (dotted line) was considered as significant. Data are shown for individual mice $(n=5)$ and as means \pm SEM.

acid substitutions in the mutants, the exact mass of the proteins was determined by means of mass spectrometry. The obtained spectra were de-convoluted using the Xtract function of Xcalibur 3.0 software (Thermo Fisher Scientific) and the experimentally determined mass was compared to the theoretical mass of the WT and the mutants (Figure 2B).

CD spectra recorded from 190 to $260 \mathrm{~nm}$ confirmed that the overall three dimensional structure of the proteins was 
TABLE 1 | Phl p 6 T cell epitopes mapped in BALB/c mice.

\begin{tabular}{llc}
\hline Peptide \# & Sequence & AA position \\
\hline 22 & DEVYNAAYNAADHAA & $65-79$ \\
28 & KYEAFVLHFSEALRI & $82-96$ \\
31 & SEALRIIAGTPEVHA & $92-106$ \\
\hline
\end{tabular}

TABLE 2 | In silico prediction of Phl p 6 stabilizing mutations using MAESTRO algorithm.

\begin{tabular}{llll}
\hline Mutant & $\boldsymbol{\Delta} \boldsymbol{\Delta}$ G_pred & c_pred & ASA \\
\hline N16M & -1.4691 & 0.886 & Buried \\
D52L & -1.3471 & 0.893 & Surface \\
N16F & -1.3469 & 0.970 & Buried \\
N16Y & -1.3052 & 0.982 & Buried \\
E39L & -1.2817 & 0.890 & Surface \\
S46Y & -1.2734 & 0.955 & Buried \\
N16L & -1.2711 & 0.816 & Buried \\
S46F & -1.2654 & 0.930 & Buried \\
M1R & -1.2512 & 0.871 & Surface \\
N16W & -1.2431 & 0.964 & Buried \\
\hline
\end{tabular}

Stabilizing mutations selected for expression and further analysis are marked in red. $\Delta \Delta G \_$pred, predicted change in free energy [ $[\mathrm{kcal} / \mathrm{mol}]$. Negative values indicate a stabilizing mutation; c_pred, confidence estimation (0-1) of the prediction; 1 , high confidence; ASA, accessible surface area: $<30 \%=$ buried, $>30 \%=$ surface exposed.

TABLE 3 | In silico prediction of Phl p 6 destabilizing mutations using MAESTRO algorithm.

\begin{tabular}{|c|c|c|c|c|c|}
\hline \multicolumn{3}{|c|}{ Surface exposed } & \multicolumn{3}{|c|}{ Buried } \\
\hline Mutant & $\Delta \Delta G \_$pred & c_pred & Mutant & $\Delta \Delta \mathrm{G} \_$pred & c_pred \\
\hline L89P & 2.0159 & 0.875 & $\mathrm{F91G}$ & 5.1619 & 0.726 \\
\hline A17P & 1.9855 & 0.831 & L64G & 5.0143 & 0.757 \\
\hline L89G & 1.9812 & 0.864 & F19G & 4.7531 & 0.727 \\
\hline A41D & 1.9513 & 0.864 & F87G & 4.6827 & 0.735 \\
\hline D82S & 1.8896 & 0.889 & L60G & 4.6052 & 0.758 \\
\hline A41P & 1.7979 & 0.831 & F91D & 4.5717 & 0.748 \\
\hline D82P & 1.7622 & 0.884 & L64E & 4.5235 & 0.807 \\
\hline $\mathrm{A} 41 \mathrm{G}$ & 1.7168 & 0.885 & L11D & 4.4678 & 0.772 \\
\hline $\mathrm{A} 41 \mathrm{~N}$ & 1.6797 & 0.855 & F38G & 4.4658 & 0.743 \\
\hline A24P & 1.6424 & 0.820 & $\mathrm{~F} 42 \mathrm{G}$ & 4.4645 & 0.733 \\
\hline
\end{tabular}

Destabilizing mutations selected for expression and further analysis are marked in green. $\Delta \Delta G \_$pred, predicted change in free energy $[\mathrm{kcal} / \mathrm{mol}]$. Positive values indicate a destabilizing mutation. c_pred, confidence estimation (0-1) of the prediction. 1 , high confidence.

not altered by introduction of the stabilizing or destabilizing mutations (Figure 2C).

Mutant D52L turned out to be truncated and was excluded from further analysis.
Stability of the proteins was assessed by CD (Figure 3A) and NMR (Figure 3C, WT, L89G, and E39L only). As predicted by MAESTRO, mutants E39L, N16M, and S46Y displayed an increased thermal stability compared to the WT protein $(\Delta \mathrm{T}$ +8.8 to $+14^{\circ} \mathrm{C}$ ) whereas the destabilized mutant L89G was less heat stable $\left(\Delta \mathrm{T}-5^{\circ} \mathrm{C}\right)$. The MAESTRO predictions were also confirmed by an accelerated molecular dynamics (aMD) simulation, with the exception of N16M, which was predicted to be extremely unstable in aMD simulations (Figures 3B, 4).

The increased fold stability of E39L and the decreased fold stability of L89G were also experimentally confirmed by NMR. Upon heating, the signal intensities of L89G began to diminish at lower temperatures, whereas the signal intensities of E39L began to diminish at higher temperatures compared to WT Phl p 6 (Figure 3C).

A more detailed analysis with X-ray crystallography of mutant S46Y showed that the 3-dimensional structure was remarkably similar to that of the WT protein. The superimposition of the crystal structures of S46Y with Phl p 6 WT revealed that the overall fold is identical, with a total root-mean-square deviation of $0.42 \mathrm{~A}$. As shown in Figure 5, the introduction of Tyr46 in the $\alpha 2$ helix, pointing into the central hydrophobic cavity, contributes to hydrophobic interactions with Phe42 within the $\alpha 2$ helix (and also Tyr68 in the neighboring $\alpha 3$ helix). These intra- and inter-helical hydrophobic interactions contribute to the overall structural stabilization.

\section{Fold-Stability of Phl p 6 Affects Proteolytic Processing and Presentation of Antigenic Peptides to T Cells}

To assess how the observed changes in thermal stability affect proteasomal degradation and thus antigen presentation, the different proteins were incubated with an endolysosomal extract of the JAWS II dendritic cell line. Proteolytic degradation of the proteins was determined by SDS-PAGE and Coomassie staining. At a $\mathrm{pH}$ of 5.2, the destabilized mutant L89G showed the fastest degradation. Of the stabilizing mutations, N16M did not increase proteolytic stability but resulted in even faster degradation compared to the WT at some early time-points. In contrast, E39L and S46Y clearly showed delayed proteolytic processing, with $\mathrm{S} 46 \mathrm{Y}$ being the most stable protein (Figure 6A, left panel). As expected, at a more acidic $\mathrm{pH}$, proteolysis was more efficient but the picture in general stayed the same (Figure 6A, right panel). As the bulk proteolysis occurred within the first $12 \mathrm{~h}$, we repeated the experiment with the WT protein, the destabilized protein $\mathrm{L} 89 \mathrm{G}$ and the most stable protein S46Y, and followed the degradation kinetics within the first $12 \mathrm{~h}$ by quantitating the generated peptides by mass spectrometry. As shown in Figure 7 ( $\mathrm{pH} \mathrm{5.2)} \mathrm{and} \mathrm{Figure} 8$ ( $\mathrm{pH} \mathrm{4.5),} \mathrm{the} \mathrm{general}$ pattern of generated peptides was very similar for the three proteins. However, the processing speed was quite different (Figure 6B). Confirming SDS-PAGE analysis, the $\mathrm{N}$ terminus of L89G was processed much faster compared to the WT protein, and also the regions containing the immunodominant epitopes 65-79 and 92-106 were degraded faster. Interestingly, 
A

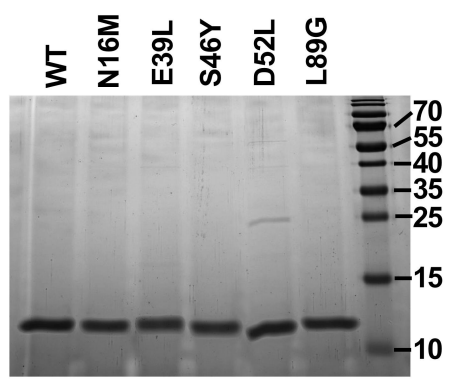

B

\begin{tabular}{lrc}
\hline Mutant & $\begin{array}{l}\text { Theoretical } \\
\text { mass (Da) }\end{array}$ & $\begin{array}{l}\text { Experimental } \\
\text { mass (Da) }\end{array}$ \\
\hline WT & 11790.09 & 11791.05 \\
\hline D52L & 11788.16 & $11264.78^{\text {a }}$ \\
\hline E39L & 11774.13 & 11774.04 \\
\hline N16M & 11807.18 & 11808.03 \\
\hline S46Y & 11866.18 & 11866.05 \\
\hline L89G & 11733.98 & 11734.98 \\
\hline a Protein was truncated & \\
\hline
\end{tabular}

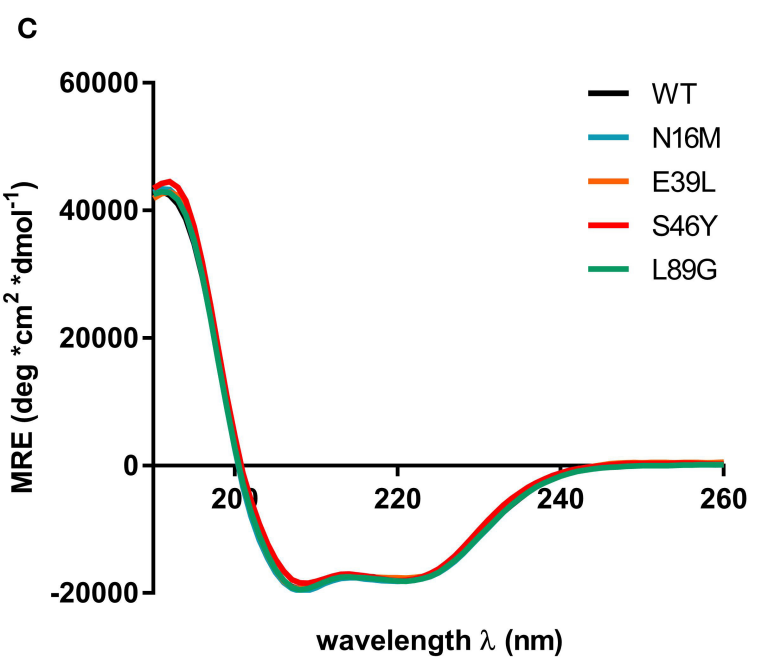

FIGURE 2 | Stabilized and destabilized variants of Phl p 6 display the characteristic alpha helical fold of the wild-type protein. Recombinant Phl p 6 (WT) and its mutants (D52L, E39L, N16M, S46Y, L89G) were expressed in E. Coli. Purified proteins were analyzed for purity by SDS-PAGE (A). Incorporation of mutations and correct size was assessed by HPLC-MS, comparing theoretical and experimental average mass (B). Full CD spectra measured at room temperature, pH 7.4 confirmed very similar folding of the WT and mutant proteins (C). CD data are shown as mean residual ellipticity (MRE).

we observed more efficient cutting right next to the $\mathrm{N}$ terminus (position 89-91) of the immunodominant epitope in mutant L89G compared to the WT protein (Figure 6C). This fits to data from aMD analysis that predicted this region to be more flexible in L89G compared to the WT (Figure 4) providing an explanation for its higher accessibility to endosomal proteases. We then used $\mathrm{T}$ cell hybridomas specific for peptide 92-106 to detect pMHCII complexes on the surface of BMDCs. BMDCs were co-cultured with this T cell hybridoma together with different concentrations of the peptide 92-106. As shown in Figure 6D, the amount of IL-2 secreted by the hybridoma cells was proportional to the peptide concentration. Thus, IL-2 secretion by $\mathrm{T}$ cell hybridomas could be used as readout for the amount of pMHCII complexes presented on the surface of BMDCs. Using peptide pulsed BMDCs as standard curve, we calculated the pMHCII concentration (as $\mu \mathrm{M}$ peptide equivalents) from BMDCs incubated with the different proteins for 16-64h (Figure 6E). Confirming the degradome data, peptide $92-106$ was much faster and more efficiently processed from the destabilized mutant L89G compared to the WT or S46Y. After $64 \mathrm{~h}$, the processing and presentation of peptide 92-106 was 3.3-fold more efficient from WT Phl p 6 and 16.7-fold more efficient from L89G compared to $\mathrm{S} 46 \mathrm{Y}$.

\section{Stabilized Mutant S46Y Shows Less IgE Binding and Induces Higher IgG2a Compared to the Wild-Type Protein and Destabilized Mutant L89G}

To investigate how altered fold stability affects immunogenicity in vivo, we immunized $\mathrm{BALB} / \mathrm{c}$ mice with $\mathrm{Phl} \mathrm{p} 6 \mathrm{WT}$, stabilized mutant S46Y, and destabilized mutant L89G by intradermal immunization (Figure 9A). To detect a modulation of immune polarization induced solely by differences in the stability of the proteins, we did not use any adjuvant. Two weeks after the third immunization, $\mathrm{Phl} \mathrm{p}$ 6-specific antibodies were measured by ELISA. Mice immunized with mutant S46Y displayed significantly higher IgG2a titers compared to the WT and L89G. In contrast, L89G induced the lowest IgG1 as well 
A

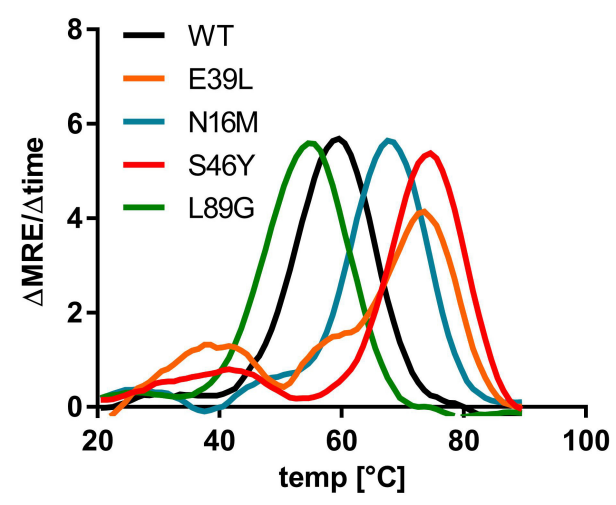

B

\begin{tabular}{lcccr}
\hline Protein & $\begin{array}{c}\Delta \Delta \mathbf{G} \\
\text { pred. }\end{array}$ & $\begin{array}{c}\text { Dihedral } \\
\text { entropy pred. } \\
\left(\mathbf{J} /\left(\mathbf{m o l}^{\star} \mathbf{K}\right)\right)\end{array}$ & $\begin{array}{c}\text { melting } \\
\text { point }\left({ }^{\circ} \mathbf{C}\right)\end{array}$ & $\begin{array}{r}\Delta \mathbf{T} \\
\left({ }^{\circ} \mathbf{C}\right) \\
\mathbf{e x p}\end{array}$ \\
\hline WT & 0 & $9859.2 \pm 21.9$ & 59.50 & 0 \\
\hline N16M & -1.4691 & ND & 68.30 & +8.8 \\
\hline E39L & -1.2817 & $9689.5 \pm 14.4$ & 72.50 & +13 \\
\hline S46Y & -1.2734 & $9690.6 \pm 15.2$ & 73.50 & +14 \\
\hline L89G & 1.9812 & $9866.6 \pm 24.8$ & 54.50 & -5 \\
\hline
\end{tabular}

c
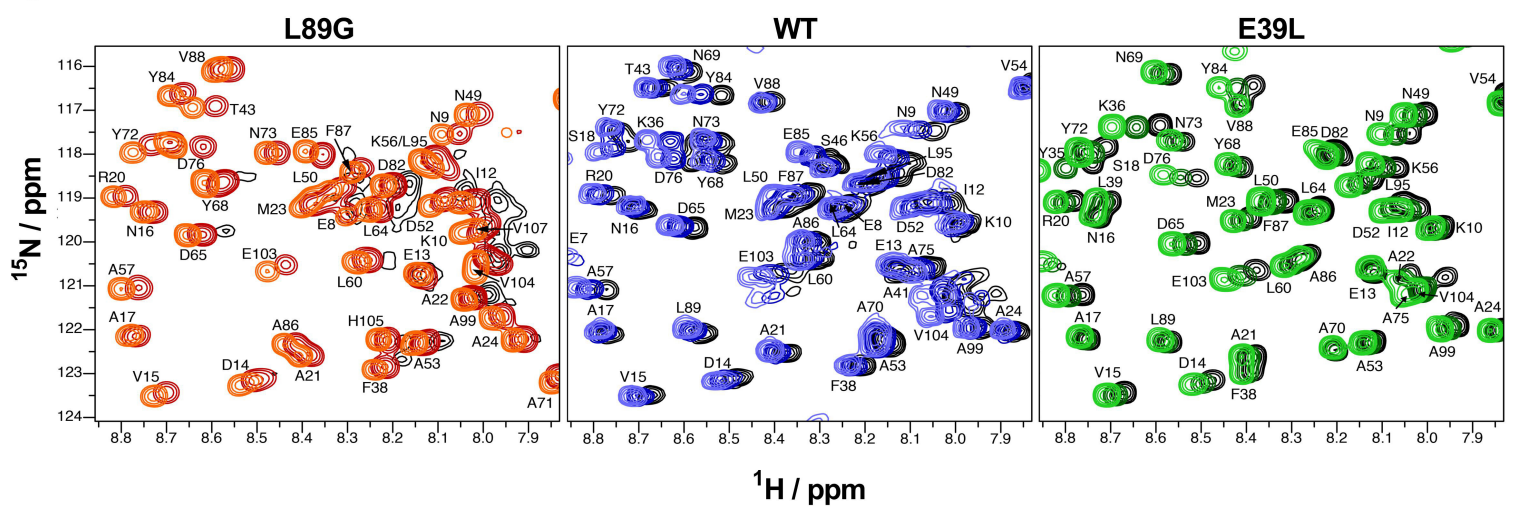

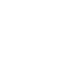

FIGURE 3 | Predicted changes in free enthalpy by introducing stabilizing or destabilizing single point mutations in Phl p 6 correlate with thermal stability. CD spectroscopy of recombinant Phl p 6 (WT) and its mutants (E39L, N16M, S46Y, L89G) was performed at $222 \mathrm{~nm}$ using a temperature ramp from 20 to $90^{\circ} \mathrm{C}$. The melting point of each protein was calculated as the inflection point (peak of the first derivative) of the mean residual ellipticity (MRE) curve (A). Predicted (pred.) changes in free enthalpy $(\Delta \Delta \mathrm{G})$ and dihedral entropy were compared to the experimentally (exp.) determined thermal melting point. The melting point shifts $(\Delta \mathrm{T})$ compared to the wild-type protein are shown. ND, not done (B). Protein backbone flexibility at different temperatures was measured by NMR. Sections of backbone amide ${ }^{1} \mathrm{H}^{15} \mathrm{~N} \mathrm{HSQC} \mathrm{NMR} \mathrm{spectra} \mathrm{of} \mathrm{Phl} \mathrm{p} 6$ recorded at $700 \mathrm{MHz}$ are shown. From left to right: destabilized mutant $\mathrm{L} 89 \mathrm{G}$ at $35^{\circ} \mathrm{C}$ (orange), $40^{\circ} \mathrm{C}$ (red) and $45^{\circ} \mathrm{C}$ (black), wild-type at $35^{\circ} \mathrm{C}$ (light blue), $40^{\circ} \mathrm{C}$ (dark blue) and $45^{\circ} \mathrm{C}$ (black), and stabilized mutant E39L at $35^{\circ} \mathrm{C}$ (light green), $40^{\circ} \mathrm{C}$ (dark green) and $45^{\circ} \mathrm{C}$ (black). Backbone amide $\mathrm{NH}$ cross peaks are labeled (C).

as IgG2a titers (Figures $\mathbf{9 B}, \mathbf{C}$ ). To rule out that this effect was due to changes in $\mathrm{B}$ cell epitopes induced by conformational changes in the mutated proteins, we tested the reactivity of sera from mice immunized with S46Y or L89G also against the homologous protein (used for immunization). As shown in Figure 10, antibodies raised against the mutant proteins recognized the WT molecule with similar efficacy compared to the homologous molecule. As expected, antibodies raised against the stabilized protein showed the lowest reactivity against the destabilized protein and vice versa. Similarly, high titered IgE sera raised against the WT protein showed intermediate reactivity with L89G and the lowest reactivity with S46Y (Figure 9D). Taken together, the differences in Phl p 6specific IgG2a titers induced by the different mutant proteins cannot be explained by conformational changes affecting $\mathrm{B}$ cell epitopes, but reflect changes in the immunogenicity of the proteins.
Although the proteins differed in their IgG2a inducing potential, all groups showed similar levels of serum IgE (RBL assay, Figure 9E) or cell bound IgE (basophil activation test, Figure 9F) after in vitro restimulation with WT Phl p 6 or an equimolar mixture of WT, S46Y, and L89G, respectively.

\section{Changing the Fold Stability of Phl p 6 Does Not Alter the Repertoire of Presented Peptides in vivo}

It has been shown previously that the fold stability of a protein influences the repertoire of presented peptides and that changing the stability can promote the presentation of hitherto not presented, so-called cryptic epitopes. To confirm our data from the in vitro degradation assay that displayed a very similar peptide profile for the different molecules, we again mapped the $\mathrm{T}$ cell 

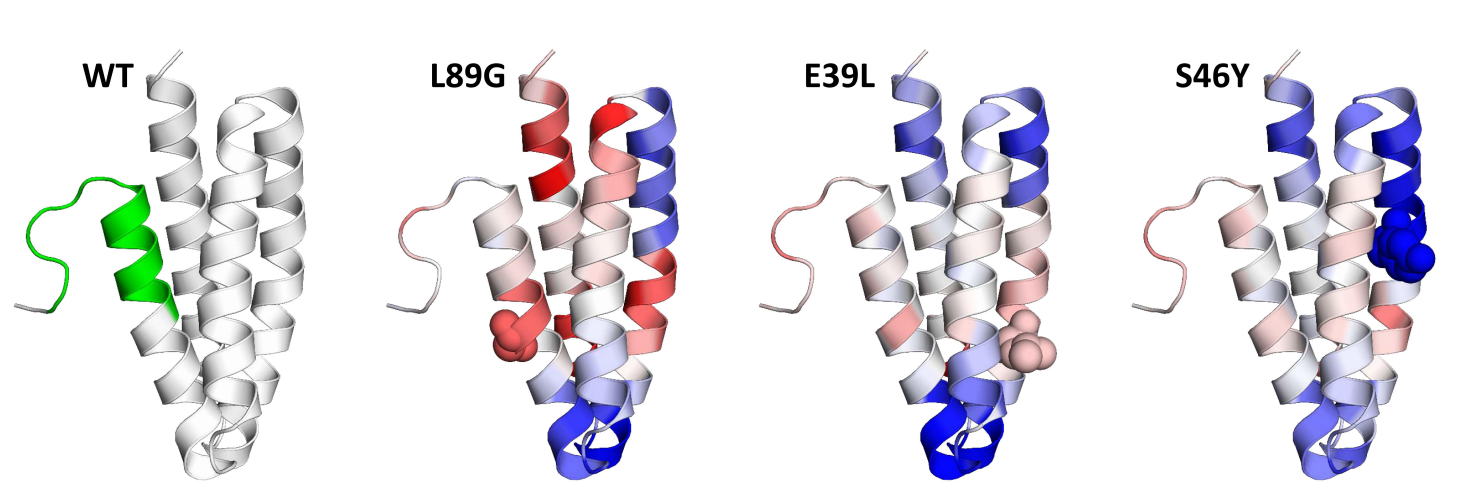

$-૪ . U U$

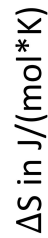

$+8.00$
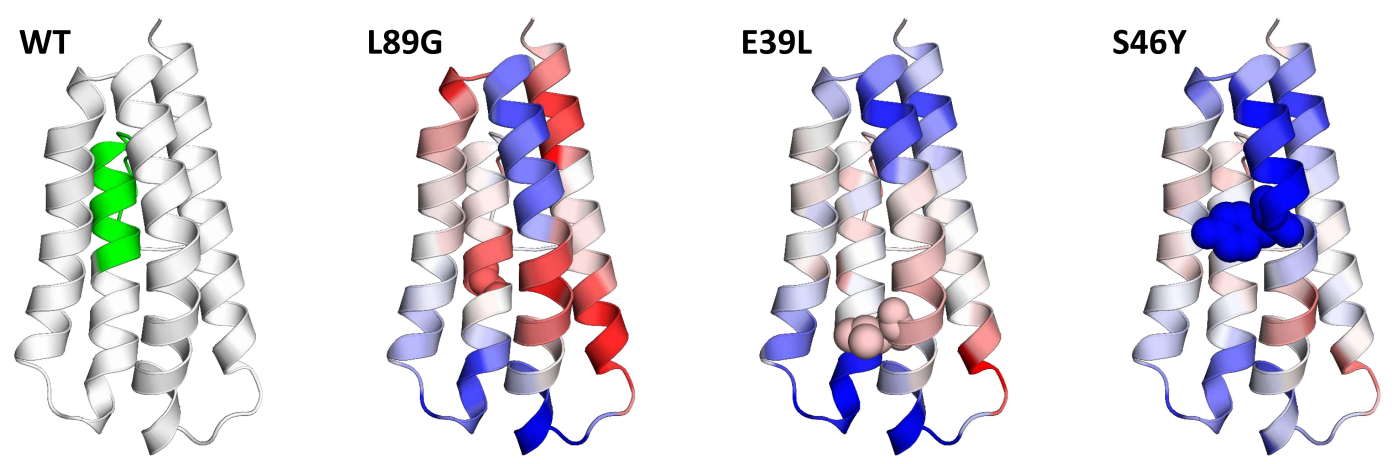

$-8.00$

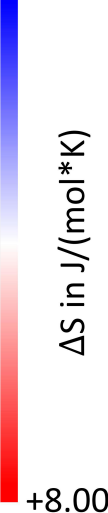

FIGURE 4 | Accelerated Molecular Dynamics (aMD) simulations confirmed enhanced flexibility of destabilized mutant L89G and reduced flexibility of the stabilized mutants E39L and S46Y compared to wild-type (WT) Phl p 6. Dihedral Entropies were calculated from aMD simulations to predict localized flexibility. The immunodominant epitope 92-106 is shown in green. Red indicates increased flexibility compared to the WT molecule and blue indicates reduced flexibility. Top and bottom panels show the same molecules in different orientations. Point mutations are displayed as spheres.
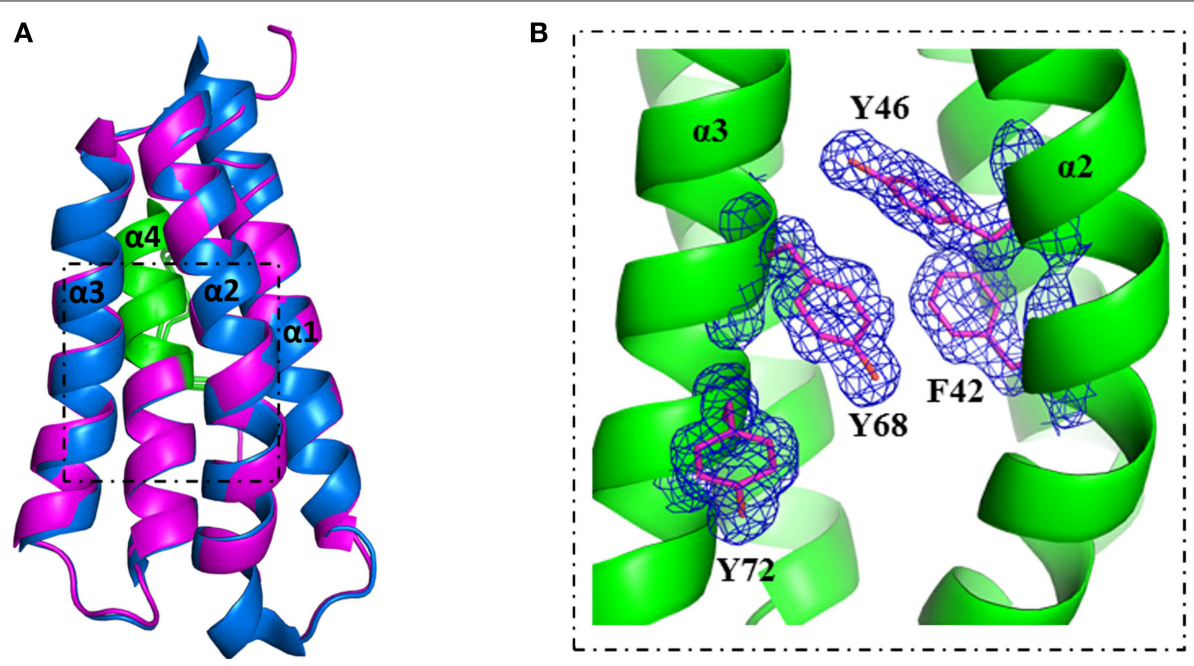

FIGURE 5 | Crystal structure of stabilized mutant S46Y revealed stabilization of the hydrophobic core. The crystal structure of Phl p 6 mutant S46Y was solved at 1.6 Å resolution (PDB: 6TRK) and structurally aligned with Phl p 6 wild-type (PDB: 1NLX). Mutant S46Y (magenta) has an overall high structural similarity (C $\alpha$-RMSD: 0.55 $\AA$ A) to the wild-type protein (blue). The immunodominant epitope (92-106) is labeled in green (A). A close up view of the hydrophobic core shows that the Tyr46 point mutation complements the aromatic stacking and thereby improves both the stability of helix $\alpha 2$ (harboring Tyr46) as well as the hydrophobic core interaction of the four-helix bundle architecture $\alpha 1-\alpha 4$ of Phl p 6. The density is displayed as a 2Fo-Fc difference map contoured at $\sigma=1.5$ (B). 
A

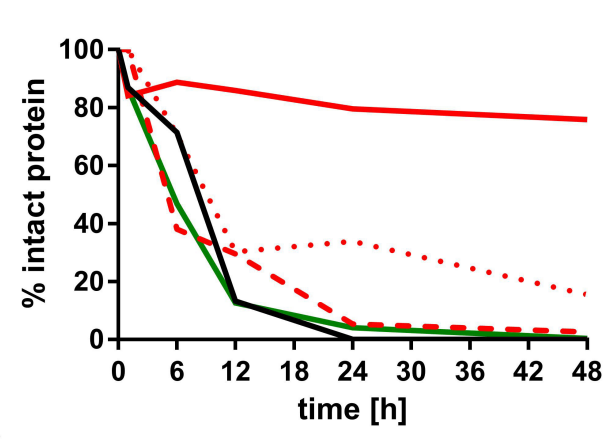

pH 4.5

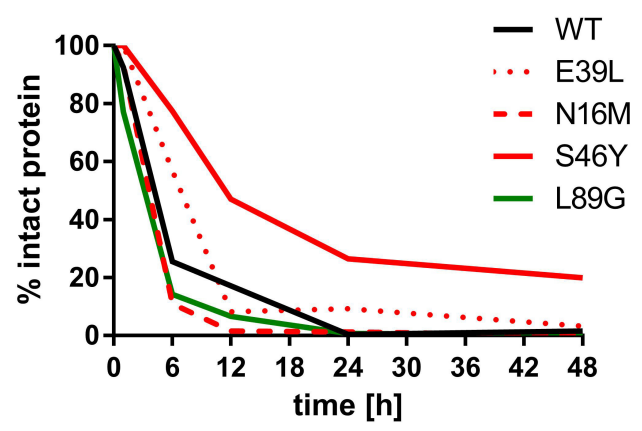

B

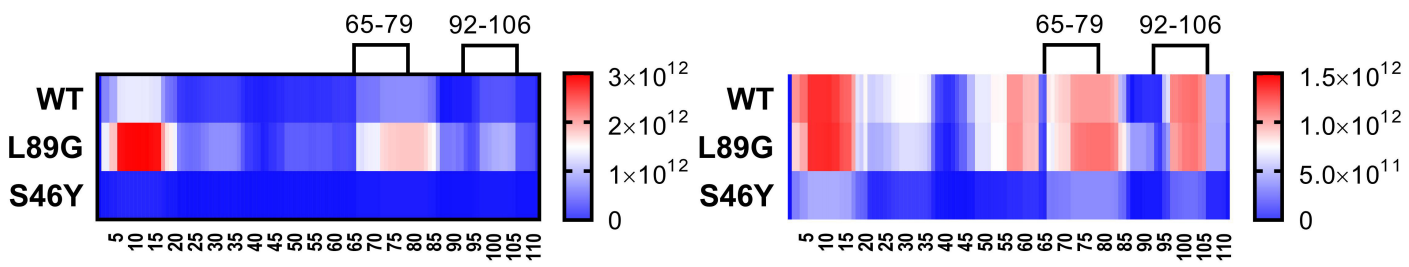

C
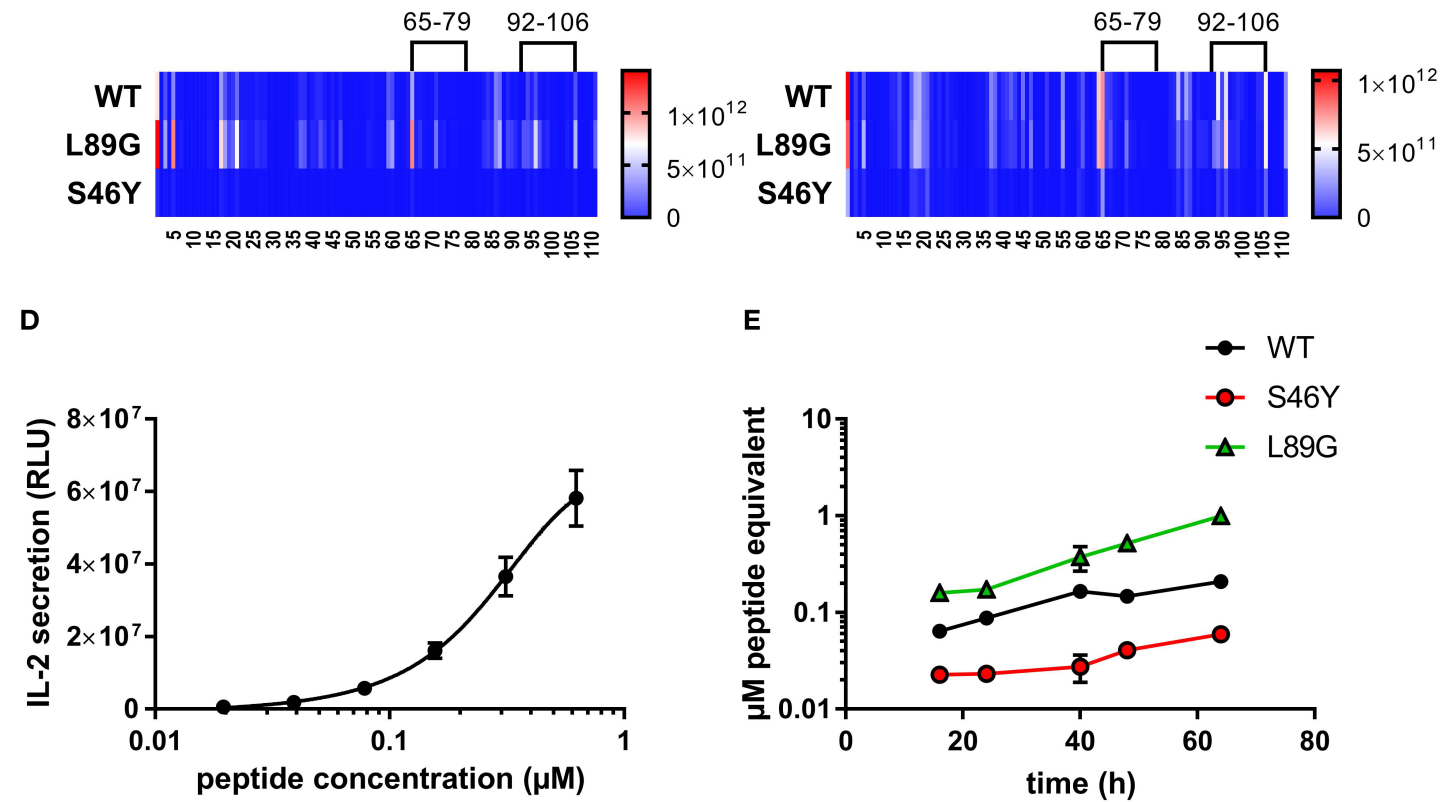

FIGURE 6 | (De)stabilization affects proteolytic processing and presentation of the immunodominant epitope 92-106 of Phl p 6. Wild-type (WT) Phl p 6, and the different mutants (E39L, N16M, S46Y, L89G) were incubated with endolysosomal preparations from JAWS-II cell line for 0, 6, 12, 24, and 48 h at pH 5.2 (left) and 4.5 (right). The percentage of remaining intact protein was estimated by SDS-PAGE and Coomassie staining (A). Peptides generated from Phl p 6 WT, L89G, and S46Y after 1, 3, 6, and $12 \mathrm{~h}$ were additionally analyzed by mass spectrometry. Peptides (B) and their respective cutting sites (C) generated earlier during the proteolytic processing are colored in red, whereas peptides that were not detected during the whole experiment are colored in blue. Presentation of the immunodominant peptide 92-106 was analyzed in vitro by co-culturing bone marrow derived dendritic cells (BMDC) with peptide specific T cell hybridoma cells. IL-2 secretion from hybridoma cells directly correlates with the amount of peptide added to the assay. Data are shown as means $\pm S D(n=3)$ of relative light units (RLU) of a luminometric ELISA (D) Using IL-2 secretion from T cell hybridomas as read-out, presentation of peptide 92-106 by BMDCs incubated with $20 \mu \mathrm{g} / \mathrm{mL}$ WT Phl p 6 or mutants L89G, and S46Y was assessed over time. Data are shown as $\mu \mathrm{M}$ peptide equivalents (the concentration of peptide needed to stimulate equivalent IL-2 secretion) (E).

epitopes of Phl p 6 in mice immunized with the WT protein or the mutants. As shown in Figure 11, mice immunized with the different Phl p 6 mutants elicited the same profile of T cell responses as the WT molecule. Only the group immunized with the destabilized mutant L89G also displayed a weak response against the region surrounding peptide 13 , which may be due to the more relaxed state of L89G $(P<0.05$ vs. S46Y, $P=0.057$ vs. WT). 

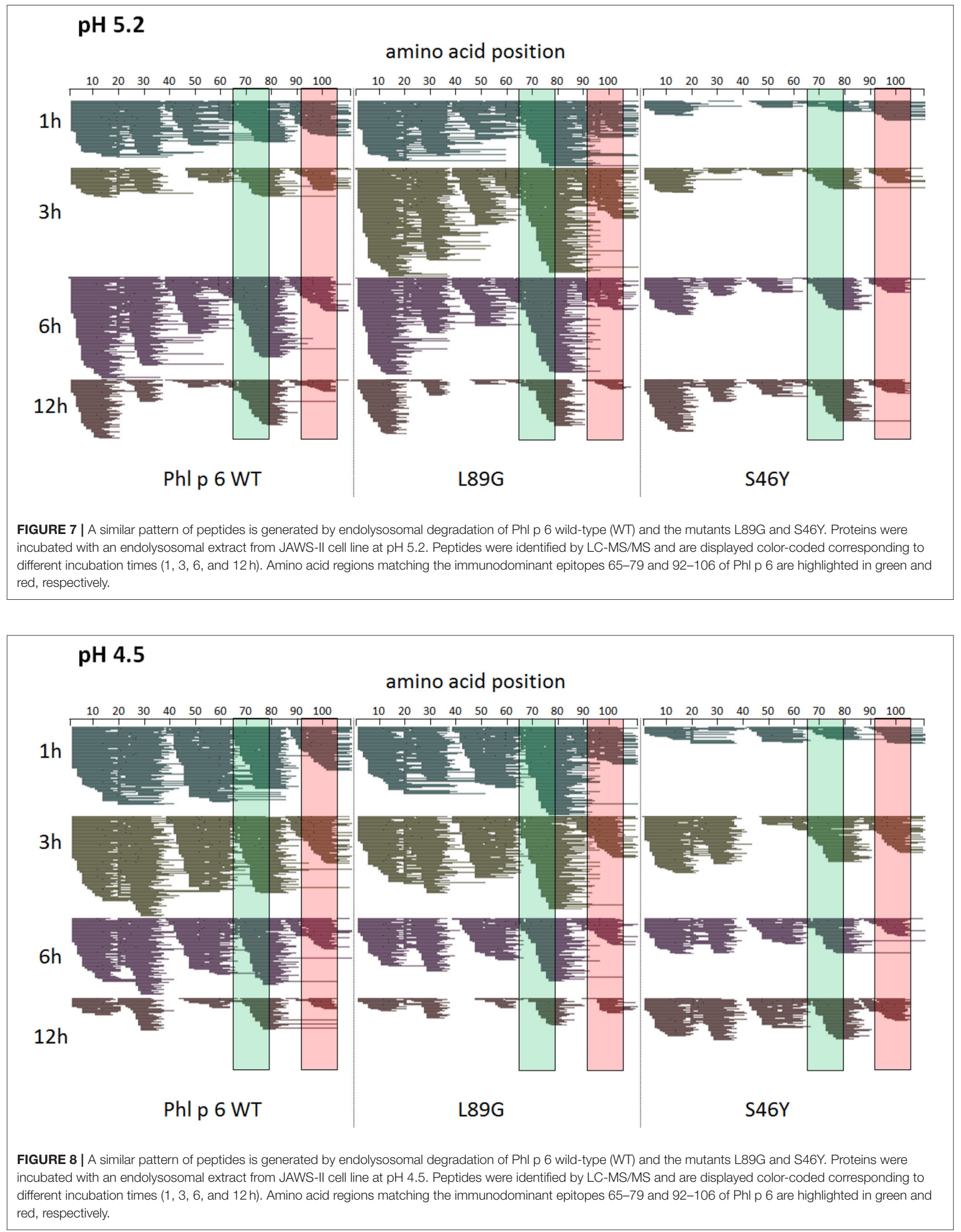
A

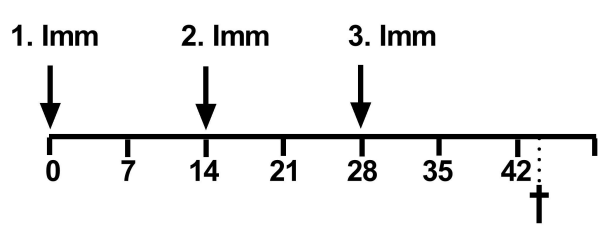

B

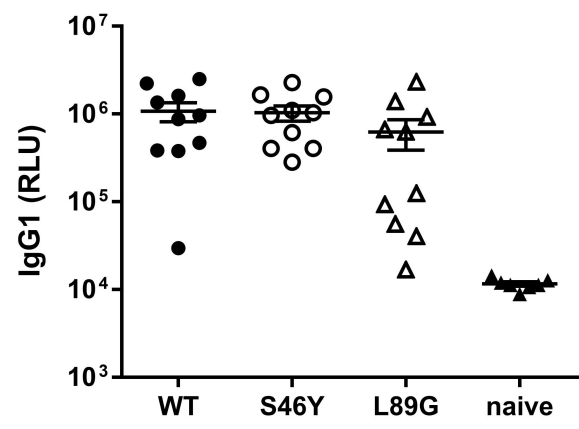

C

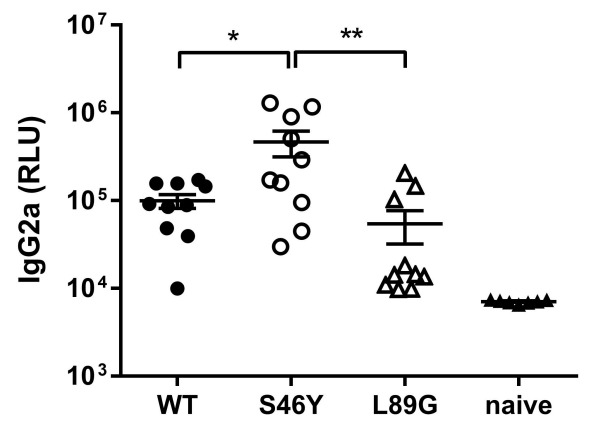

D

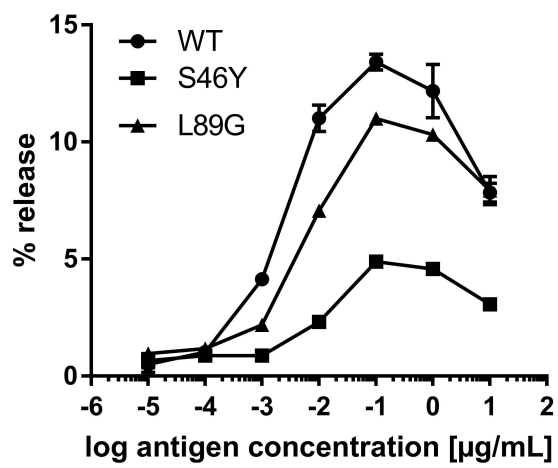

E

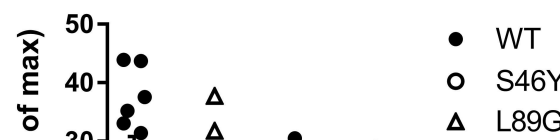

$\Delta$ L89G

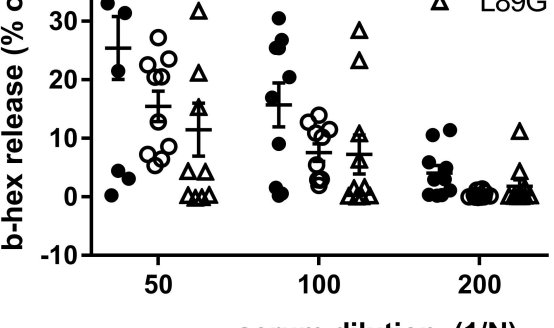

$\mathbf{F}$

serum dilution $(1 / \mathrm{N})$

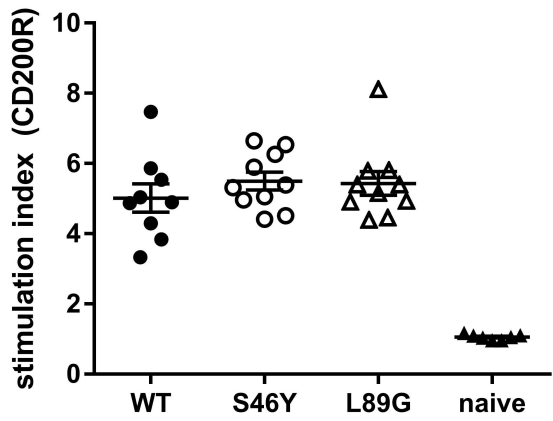

FIGURE 9 | Stabilization of Phl p 6 shifts immune responses toward Thelper 1 reactions. For assessment of in vivo immunogenicity, BALB/c mice were immunized three times at 2-week intervals by intradermal injections and sacrificed 2 weeks after the last immunization (A). Phl p 6-specific serum IgG1 (B) and IgG2a (C) were measured by luminometric ELISA at serum dilutions of 1:100,000 and 1:100, respectively, lying within the linear range of the assay. Data are shown as means \pm SEM $(n=10)$ of relative light units (RLU). IgE crosslinking capacity of the different proteins was tested using RBL cells loaded with high titered Phl p 6 WT specific lgE. Increasing concentrations of the different proteins were added and cross-linking induced beta-hexosaminidase (b-hex) release is presented as percentage of maximum release induced by Triton-X100 cell lysis ( $n=3$, means \pm SD) (D). Biologically active lgE in sera from immunized mice (WT, L89G, S46Y) were measured by incubating RBL cells with serum $(n=10$, means \pm SEM) at indicated dilutions, followed by cross-linking with WT Phl p 6 (E). Cell bound lgE in blood from immunized (WT, L89G, S46Y) and naïve control mice $(n=10)$ was measured by basophil activation test after in vitro stimulation of whole blood samples with $10 \mathrm{ng}$ of an equimolar mixture of WT, S46Y, and L89G protein. IgE cross-linking induced upregulation of activation marker CD200R was measured by flow cytometry. Data are shown as means \pm SEM of stimulation indices (SI) (F). ${ }^{\star \star} P<0.01,{ }^{\star} P<0.05$.

\section{Stabilized Mutant S46Y Shifts the Immune Polarization Toward Inflammatory Response Types}

The amount of pMHCII complexes presented on the surface of APCs has been shown to influence the immune polarization of $\mathrm{T}$ cells in vitro and in vivo. Thus, we hypothesized that the different processing speed of mutant proteins with increased or reduced fold stability might also impact the immune polarization. Therefore, we stimulated splenocytes from immunized mice with the immunodominant peptides 65-79 or 92-106 and measured cytokine secretion in culture supernatants. Although stimulation with peptides 65-79 


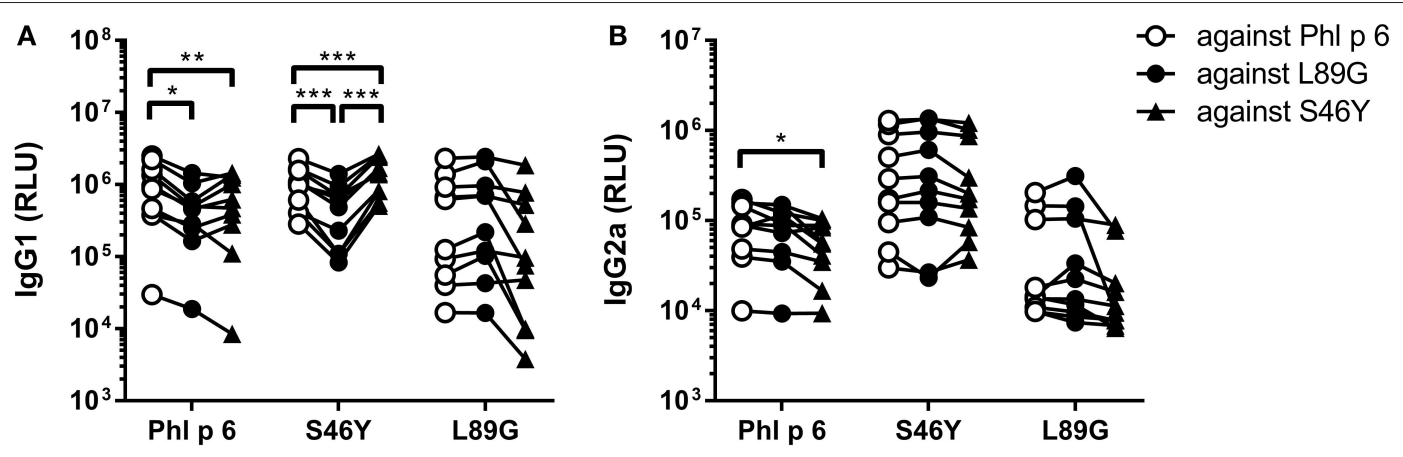

FIGURE 10 | Antibodies induced by immunization with L89G and S46Y bind WT Phl p 6 with similar efficacy compared to the homologous protein. Sera ( $n=10$ ) were analyzed for their reactivity against Phl p 6 WT and the different mutant proteins using a luminometric ELISA. IgG1 (A) and IgG2a (B) data are shown as relative light units (RLU). Individual serum samples tested against the different proteins are connected by lines. Statistical differences were assessed by two-way RM ANOVA followed by Tukey's post-hoc test. ${ }^{*} P<0.05,{ }^{* *} P<0.01,{ }^{* \star *} P<0.001$.

and 92-106 induced similar $\mathrm{T}$ cell proliferation in mice immunized with the wild-type protein and the mutants (Figure 11), the groups significantly differed in their cytokine profile. In line with the increased IgG2a levels indicating an enhanced TH1 immune response (Figure 9B), splenocytes derived from mice immunized with the stabilized mutant S46Y, secreted significantly higher levels of TH1 cytokines TNF- $\alpha$ and IFN- $\gamma$ after stimulation with peptide 65-79 (Figure 12A).

Similarly, TH17 cytokines IL-17A (not shown), IL-17F, and IL-21 (Figure 12C) were increased. In contrast, TH2 cytokines IL-4, IL-5, and IL-13 were similar between all groups, with the exception of IL-4, which was slightly elevated in the S46Y group after stimulation with peptide 92-106 (Figure 12B). The regulatory cytokine IL-10 was also elevated in the S46Y group (Figure 12D), which might reflect a counter regulation due to the inflammatory response induced by S46Y.

\section{DISCUSSION}

Enormous efforts have been undertaken to understand and modulate activation and differentiation of TH cells into different effector cell types. The classical qualitative model postulates that MHCII-TCR interaction (signal 1) and co-stimulation via CD28 (signal 2) trigger activation and proliferation of naïve $\mathrm{TH}$ cells, whereas cytokines from extrinsic sources such as the APC itself or innate bystander cells largely determine immune polarization. In line with this, individual cytokines or combinations thereof have been identified to drive the development of specific $\mathrm{T}$ cell subsets, such as TH1 (IL-12), TH2 (IL-4), TH17 (TGF- $\beta$, IL-6, IL-21), Tfh (IL-21), TH9 (TGF- $\beta$, IL-4), iTreg (TGF- $\beta$, IL- 2 ), and Tr1 (IL-10, IL-27) cells (53). However, accumulating evidence suggests that also the quantity and the quality of the TCR signaling induced by pMHCII stimulation plays a crucial role in $\mathrm{T}$ cell polarization. In support of this quantitative model, it has been shown that high doses of antigen increase the number of pMHCII complexes presented on the surface of the APC affecting TCR signal strength and/or duration. In summary, these studies suggest that weak
TCR:pMHCII interactions favor TH2 or Tfh responses, whereas strong interactions induce TH1 responses (54). This model has important implications for our understanding why some proteins, such as allergens, seem to have intrinsic features that drive a certain type of immune polarization. We have previously suggested that protein fold stability represents such an intrinsic feature that has significant impact on the immunogenicity and allergenicity of proteins (55). Efficient antigen processing relies on antigen unfolding within the endolysosome. This process is mediated by endolysosomal acidification, and proteolytic cleavage of proteins by resident proteases, which preferentially degrade proteins in an unfolded state, facilitating access to the protein backbone (56). Additionally, proteins in a more relaxed state can serve as better substrates for binding to MHC II, which in turn can protect epitopes from further proteolytic degradation (57). However, there is very little in vivo data available focusing on the impact of fold stability on polarization of the immune response. Furthermore, studies investigating alterations of immune responses caused by modulated antigen stability have often been contradictory (19).

In our current study, we used an unbiased in silico approach to predict stability changes upon the introduction of single point mutations leaving known $\mathrm{T}$ cell epitopes and the overall structure unchanged. In silico predicted changes in free enthalpy $(\Delta \Delta \mathrm{G})$ correlated well with experimentally determined thermal stability as measured by CD spectroscopy and NMR. In the destabilized mutant L89G, a surface exposed leucine was replaced by a glycine, thereby removing the side chain at this position, giving adjacent amino acids additional flexibility, which was confirmed by aMD simulations. In mutant S46Y, a buried polar amino acid was replaced by a hydrophobic amino acid. Such replacements have been referred to as "hydrophobic core packing" and reported to have stabilizing effects on the protein structure by increasing the overall hydrophobicity within the protein core (22). Furthermore, the removal of cavities, by introduction of point mutations, has been shown to have stabilizing effects as well (58-60). During antigen processing, protein unfolding represents an indispensable step, as proteases 


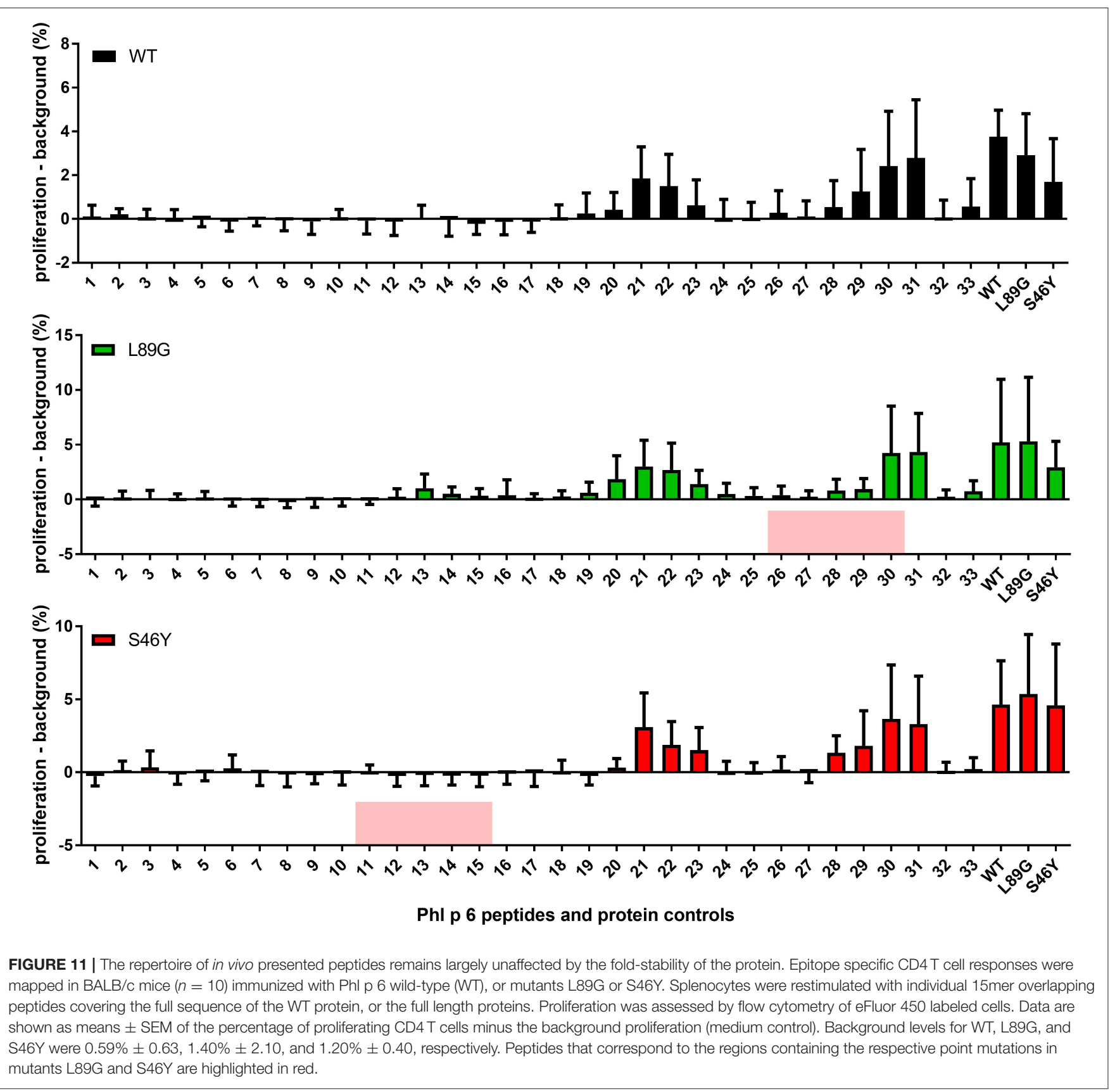

require access to the backbone of the proteins for efficient cleavage (56). Following cellular uptake, antigens are exposed to a continuous drop in $\mathrm{pH}$ from mild acidic conditions in the early endolysosome down to $\mathrm{pH} 4.0$ in terminal lysosomes. Fold stability, in particular resistance to $\mathrm{pH}$-mediated denaturation, determines the extent and time-point of unfolding during lysosomal acidification. It has been shown that early endosomes ( $\mathrm{pH} \sim 6$ ) and terminal lysosomes ( $\mathrm{pH} \sim 4.0-4.5$ ) are poor in MHC II molecules whereas high quantities of MHC II are found in the late endosome ( $\mathrm{pH} \sim 4.5-5.5$ ), where the majority of MHC II loading takes place (61). We propose a model in which efficient antigen processing requires high fold stability in the early endosome, allowing the accumulation of intact antigen in the late endosome where it becomes sensitive to $\mathrm{pH}$ mediated unfolding, facilitating efficient proteolytic degradation (55). Thermal stability of Phl p 6 and its mutants correlated remarkably well with the speed of proteolytic digestion using endosomal extracts (Figures 6A,B) with the exception of N16M, which despite a considerable shift in melting point $\left(+8.8^{\circ} \mathrm{C}\right) \mathrm{did}$ not display enhanced protease resistance. This is in line with aMD simulations that indicated N16M to be extremely unstable, showing fast unfolding even at the nano-second timescale. Thus, 

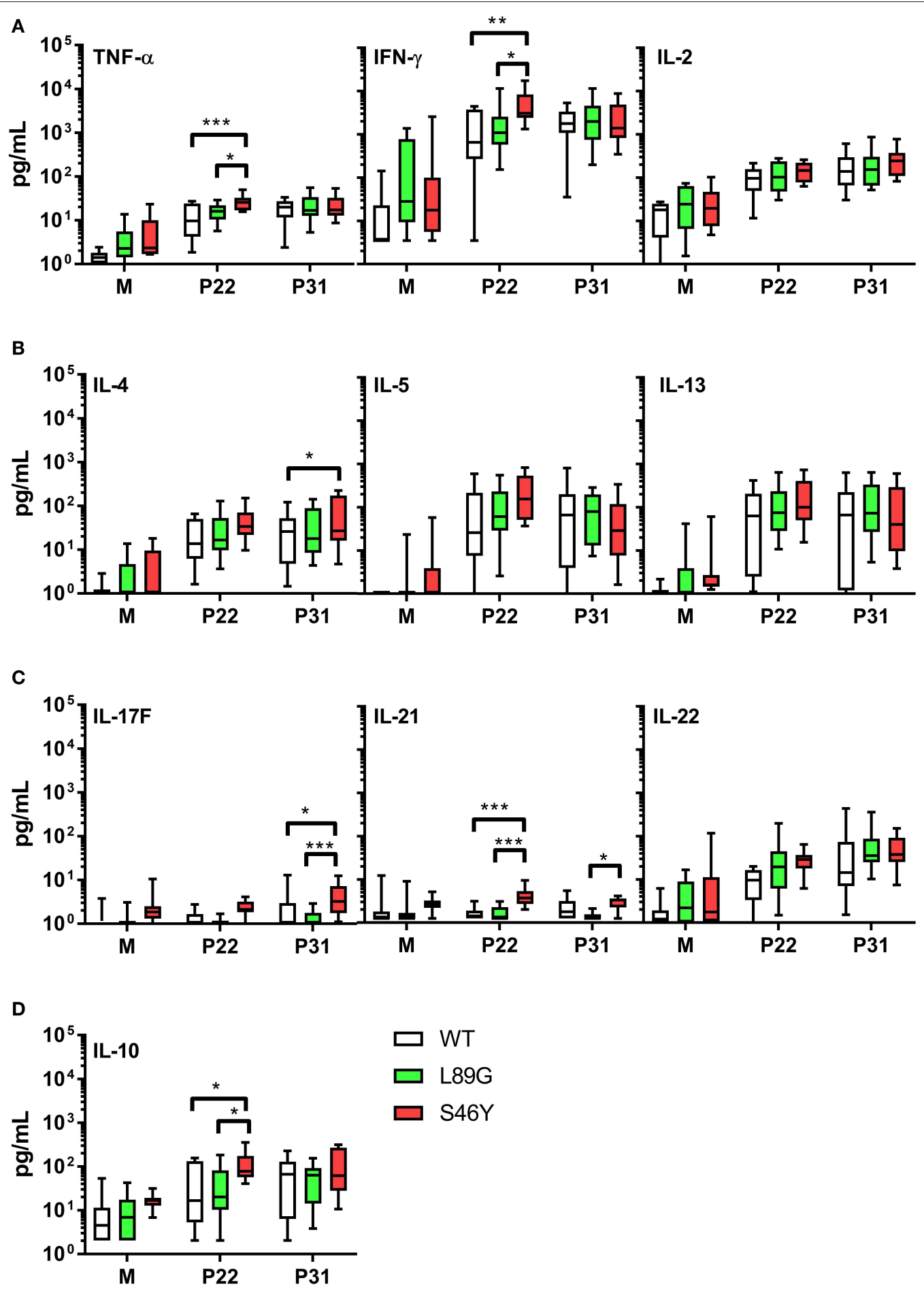

FIGURE 12 | Immunization with stabilized mutant S46Y shifts the T cell response toward TH1/TH17. BALB/c mice were immunized with Phl p 6 wild-type (WT) protein, and mutants L89G and S46Y. Splenocytes from immunized mice were restimulated in vitro with peptide 65-79 (P22) or 92-106 (P31) or remained unstimulated (medium control, M) for 3 days. Cytokine concentrations in cell culture supernatants were measured by a flow cytometry based multiplex bead assay. Data are shown as box (25th-75th percentile) and whiskers (min to max) plots $(n=10)$. Statistical differences were assessed by two-way RM ANOVA followed by Tukey's post-hoc test. ${ }^{\star \star *} P<0.001,{ }^{* *} P<0.01,{ }^{*} P<0.05$. 
aMD simulations may be a very useful tool to eliminate false positives from the MAESTRO in silico predictions. To assess the presentation of the immunodominant T cell epitope 92-106 in the context of proteins with different fold stability, we used BMDCs and a $\mathrm{T}$ cell hybridoma line specific for the respective pMHCII complex. IL-2 secretion by the hybridoma cells directly correlated with the amount of peptide loaded on BMDCs and thus represents a sensitive biological surrogate parameter to determine the amount of pMHCII complexes on the surface of APCs. We found that peptide 92-106 was much faster and more efficiently processed from L89G compared to the WT, whereas presentation was almost abrogated in the most rigid mutant S46Y. This is in line with the enhanced susceptibility to proteases of L89G observed in the degradome assay. We have previously found that immunodominant peptides from Bet v 1.0101 or tropomyosin $(55,62)$ are quickly degraded in the degradome assay, but nevertheless are effectively presented by BMDCs in vitro, supporting the concept of "bind first, cut later." Kim et al. have shown that immunodominant epitopes are protected from further degradation by binding to MHC II, whereas epitopes sensitive to DM-mediated dissociation are destroyed by cathepsins $(57,63)$. Data on the protein dynamics from aMD simulations indicated that the introduction of glycin 89 enhanced the flexibility in the alpha helix (91-96) adjacent to the epitope (Figure 4) facilitating access to additional cleavage sites (Figures 6C,D) and/or binding to MHC II. Our finding that the efficacy of presentation for a given epitope is largely dependent on the fold stability of the protein is in line with both models.

Since we also wanted to investigate the impact of fold stability on the immunogenicity of the generated Phl p 6 derivatives in an adjuvant free setting in vivo, it was crucial to avoid any contaminations, which might modulate the antigen triggered immune response, in particular remaining LPS within the protein solutions. It was previously shown, that LPS concentrations of $0.2 \mathrm{ng} / \mathrm{ml}$ are sufficient to activate human monocytes and $\mathrm{CD}_{1} \mathrm{c}^{+} \mathrm{DCs}$ in vitro (29). LPS from our recombinant proteins was therefore removed to $<0.1 \mathrm{pg}$ per $\mu \mathrm{g}$ protein, which corresponds to $<2 \mathrm{pg} / \mathrm{ml}$ in the in vitro experiments and to $<1$ pg LPS per mouse for each immunization in the in vivo experiments. Therefore, we can exclude LPS induced effects in our experiments. Despite the much slower protein degradation in vitro, S46Y turned out to be significantly more immunogenic in terms of IgG2a induction, while IgG1 levels, serum and cell bound $\operatorname{IgE}$ remained unaltered (Figure 9). The observed increase in IgG2a antibodies is in line with a significantly altered cytokine response, showing a shift toward secretion of TH1 and TH17 cytokines after stimulation with the immunodominant peptides (Figure 12). Various other studies have investigated the effect of fold stability on the immunogenicity of proteins and the subsequent $\mathrm{T}$ cell polarization with divergent results. Some reported a higher immunogenicity of stabilized proteins with respect to antibody titers $(64,65)$. Others have found exactly the opposite, namely a reduced immunogenicity of stabilized variants $(66,67)$ and an increased immune response due to an elevated peptide presentation in destabilized proteins (56). Further, the immunogenicity is reduced upon protein denaturation (68) and increased protease susceptibility (23). With regards to $\mathrm{T}$ cell polarization, a stabilized form of Bet $\mathrm{v} 1$, including a short Mal d 1 sequence, elicited an increased TH1 response compared to the wild-type Bet v 1 (65). In contrast, we found an increased $\mathrm{TH} 2$ response for Bet $\mathrm{v} 1$ containing stabilizing point mutations in comparison to WT Bet v 1 (55). For hen egg lysozyme (HEL), induction of an increased amount of IL-4 could be detected for the destabilized variant, suggesting an increased $\mathrm{TH} 2$ response. However, the amount of IFN- $\gamma$ was also elevated after immunization with the destabilized HEL and not detectable for the stabilized form, indicating an overall higher immune response (69). We postulate a model (19) where proteins with high protease susceptibility are rapidly degraded in the early endosome, resulting in low numbers of pMHCII complexes to be loaded in the late endosomal MHC class II compartment (MIIC). Only proteins with sufficient stability survive long enough to reach the MIIC where they are processed and loaded on MHC II. However, hyperstable proteins that fail to unfold in the MIIC cannot be processed at all and are thus not immunogenic (55). Consequently, an optimal stability will generate a high density of pMHCII, which is important for TCR signaling and induction of a TH1 response $(9,70)$. Deviation from this optimum-in both directions-can result in $\mathrm{TH} 2$ polarization. This would explain, why in different studies, depending on the initial stability of the used protein, additional stabilization can lead to divergent results.

Mutations in the native protein $(71,72)$, very high antigen concentrations, or unusual protein conformations $(73,74)$ have been shown to induce presentation of so-called cryptic epitopes that are usually not presented. In this context, we investigated whether changes in fold-stability, which resulted in substantial changes in the processing kinetics in vitro, would also change the epitope usage in vivo. However, as shown in Figure 11, the epitope usage between WT, L89G, and S46Y remained largely unchanged, with the exception of the region around peptide 13, which was only recognized by $\mathrm{T}$ cells from mice immunized with L89G, indicating that the more relaxed conformation of L89G resulted indeed in the presentation of a cryptic epitope.

In summary, MAESTRO was very efficient in detecting single point mutations that increase or reduce fold-stability, at least for small, alpha-helical proteins such as Bet v 1 (55) or Phl p 6, and aMD simulations could be successfully used to eliminate false positives. Thermal stability correlated well with susceptibility to protease resistance and presentation of pMHCII on the surface of BMDCs in vitro. Surprisingly, more efficient processing in these in vitro systems did not correlate with enhanced immunogenicity and $\mathrm{TH} 1$ polarization in vivo. On the contrary, the more stable mutant S46Y turned out to be more immunogenic and TH1 polarizing than the destabilized mutant L89G. Potentially, in the in vivo setting, either the enhanced protease resistance of S46Y provides the molecule with the advantage of longer extracellular survival (depot effect), or the in vivo situation requires slower antigen processing compared to the in vitro assays. This applies especially for intradermal injections (as used in this study) where skin dendritic cells take up the antigen and migrate to skin draining lymph nodes during a time-period of 24$48 \mathrm{~h}$ before they encounter their matching $\mathrm{T}$ cells. Additional 
experiments are necessary to test this hypothesis. Taken together, we have shown that in silico evaluation of fold stability modulated proteins has the potential to optimize and polarize immune responses, which opens the door to more efficient design of molecular vaccines.

\section{DATA AVAILABILITY STATEMENT}

The datasets generated for this study can be found in the Protein Data Bank under the entry code 6TRK.

\section{ETHICS STATEMENT}

The animal study was reviewed and approved by Austrian Ministry of Education, Science and Research (permit no. BMWF66.012/0013-WF/V/3b/2017].

\section{AUTHOR CONTRIBUTIONS}

PW, SSt, SSc, IJ, and RW expressed, purified, and characterized recombinant proteins and performed in vitro degradation and presentation assays and in vivo experiments. LS, CB, and $\mathrm{CH}$ performed mass spectrometry and analyzed the respective data. WS and JB performed X-ray crystallography and analyzed the structures. $\mathrm{FH}, \mathrm{AK}$, and $\mathrm{KL}$ developed aMD algorithms and performed the respective analyses. VD and MT expressed

\section{REFERENCES}

1. Rosenberg AS. Effects of protein aggregates: an immunologic perspective. AAPS J. (2006) 8:E501-7. doi: 10.1208/aapsj080359

2. Almond RJ, Flanagan BF, Antonopoulos A, Haslam SM, Dell A, Kimber I, et al. Differential immunogenicity and allergenicity of native and recombinant human lactoferrins: role of glycosylation. Eur J Immunol. (2013) 43:170-81. doi: 10.1002/eji.201142345

3. Thomas WR. Molecular mimicry as the key to the dominance of the house dust mite allergen Der p 2. Expert Rev Clin Immunol. (2009) 5:233-7. doi: 10.1586/eci.09.5

4. Sehgal N, Custovic A, Woodcock A. Potential roles in rhinitis for protease and other enzymatic activities of allergens. Curr Allergy Asthma Rep. (2005) 5:221-6. doi: 10.1007/s11882-005-0041-9

5. Lever M, Maini PK, Van Der Merwe PA, Dushek O. Phenotypic models of T cell activation. Nat Rev Immunol. (2014) 14:619-29. doi: 10.1038/nri3728

6. Constant S, Pfeiffer C, Woodard A, Pasqualini T, Bottomly K. Extent of $\mathrm{T}$ cell receptor ligation can determine the functional differentiation of naive CD4+ T cells. J Exp Med. (1995) 182:1591-6. doi: 10.1084/jem.182. 5.1591

7. Hosken NA, Shibuya K, Heath AW, Murphy KM, O'garra A. The effect of antigen dose on CD4+ $\mathrm{T}$ helper cell phenotype development in a $\mathrm{T}$ cell receptor-alpha beta-transgenic model. J Exp Med. (1995) 182:1579-84. doi: 10.1084 /jem.182.5.1579

8. Van Panhuys N, Klauschen F, Germain RN. T-cell-receptor-dependent signal intensity dominantly controls $\mathrm{CD} 4(+) \mathrm{T}$ cell polarization in vivo. Immunity. (2014) 41:63-74. doi: 10.1016/j.immuni.2014.06.003

9. Van Panhuys N. TCR signal strength alters T-DC activation and interaction times and directs the outcome of differentiation. Front Immunol. (2016) 7:6. doi: 10.3389/fimmu.2016.00006

10. Fazilleau N, Mcheyzer-Williams LJ, Rosen H, Mcheyzer-Williams MG. The function of follicular helper T cells is regulated by the strength of $\mathrm{T}$ cell antigen receptor binding. Nat Immunol. (2009) 10:375-84. doi: 10.1038/ni.1704 proteins for NMR and performed NMR spectroscopy. JL and PL designed the MAESTRO algorithm, modeled the Phl p 6 structure for analysis and performed MAESTRO analyses. SM and $\mathrm{JH}-\mathrm{H}$ performed masked LPS assays and analyzed the respective data. SSc and RW designed the study and wrote the manuscript. All authors reviewed, revised, and approved the final manuscript.

\section{FUNDING}

This work was supported by the Austrian Science Fund (FWF) projects \#P26997B13 (RW), \#P30737 $(\mathrm{KL})$, and \#W1213 (CH) and the Austrian Research Promotion Agency FFG, West Austrian BioNMR 858017 (MT).

\section{ACKNOWLEDGMENTS}

This manuscript has been released as a pre-print at bioRxiv.org (BIORXIV/2020/967265] (75).

\section{SUPPLEMENTARY MATERIAL}

The Supplementary Material for this article can be found online at: https://www.frontiersin.org/articles/10.3389/fimmu. 2020.01824/full\#supplementary-material

11. Deenick EK, Chan A, Ma CS, Gatto D, Schwartzberg PL, Brink R, et al. Follicular helper $\mathrm{T}$ cell differentiation requires continuous antigen presentation that is independent of unique B cell signaling. Immunity. (2010) 33:241-53. doi: 10.1016/j.immuni.2010.07.015

12. Baumjohann D, Preite S, Reboldi A, Ronchi F, Ansel KM, Lanzavecchia $A$, et al. Persistent antigen and germinal center B cells sustain $T$ follicular helper cell responses and phenotype. Immunity. (2013) 38:596-605. doi: 10.1016/j.immuni.2012.11.020

13. Gottschalk RA, Corse E, Allison JP. TCR ligand density and affinity determine peripheral induction of Foxp3 in vivo. J Exp Med. (2010) 207:1701-11. doi: 10.1084/jem.20091999

14. Gottschalk RA, Hathorn MM, Beuneu H, Corse E, Dustin ML, AltanBonnet $\mathrm{G}$, et al. Distinct influences of peptide-MHC quality and quantity on in vivo T-cell responses. Proc Natl Acad Sci USA. (2012) 109:881-6. doi: $10.1073 /$ pnas.1119763109

15. Iezzi G, Sonderegger I, Ampenberger F, Schmitz N, Marsland BJ, Kopf M. CD40-CD40L cross-talk integrates strong antigenic signals and microbial stimuli to induce development of IL-17-producing CD4+ T cells. Proc Natl Acad Sci USA. (2009) 106:876-81. doi: 10.1073/pnas.0810769106

16. Dadaglio G, Moukrim Z, Lo-Man R, Sheshko V, Sebo P, Leclerc C. Induction of a polarized Th1 response by insertion of multiple copies of a viral T-cell epitope into adenylate cyclase of Bordetella pertussis. Infect Immun. (2000) 68:3867-72. doi: 10.1128/IAI.68.7.3867-3872.2000

17. Turk B. Targeting proteases: successes, failures and future prospects. Nat Rev Drug Discov. (2006) 5:785-99. doi: 10.1038/nrd2092

18. Cudic M, Fields GB. Extracellular proteases as targets for drug development. Curr Protein Pept Sci. (2009) 10:297-307. doi: 10.2174/138920309788922207

19. Scheiblhofer S, Laimer J, Machado Y, Weiss R, Thalhamer J. Influence of protein fold stability on immunogenicity and its implications for vaccine design. Expert Rev Vaccines. (2017) 16:479-89. doi: 10.1080/14760584.2017.1306441

20. Pantoliano MW, Ladner RC, Bryan PN, Rollence ML, Wood JF, Poulos TL. Protein engineering of subtilisin BPN': enhanced stabilization through the 
introduction of two cysteines to form a disulfide bond. Biochemistry. (1987) 26:2077-82. doi: 10.1021/bi00382a002

21. Mansfeld J, Vriend G, Dijkstra BW, Veltman OR, Van Den Burg B, Venema G, et al. Extreme stabilization of a thermolysin-like protease by an engineered disulfide bond. J Biol Chem. (1997) 272:11152-6. doi: $10.1074 /$ jbc.272.17.11152

22. Lee B, Vasmatzis G. Stabilization of protein structures. Curr Opin Biotechnol. (1997) 8:423-8. doi: 10.1016/S0958-1669(97)80063-8

23. Delamarre L, Couture R, Mellman I, Trombetta ES. Enhancing immunogenicity by limiting susceptibility to lysosomal proteolysis. $J$ Exp Med. (2006) 203:2049-55. doi: 10.1084/jem.20052442

24. Arancibia S, Del Campo M, Nova E, Salazar F, Becker MI. Enhanced structural stability of Concholepas hemocyanin increases its immunogenicity and maintains its non-specific immunostimulatory effects. Eur J Immunol. (2012) 42:688-99. doi: 10.1002/eji.201142011

25. Laimer J, Hofer H, Fritz M, Wegenkittl S, Lackner P. MAESTRO-multi agent stability prediction upon point mutations. BMC Bioinformatics. (2015) 16:116. doi: 10.1186/s12859-015-0548-6

26. Pettersen EF, Goddard TD, Huang CC, Couch GS, Greenblatt DM, Meng EC, et al. UCSF Chimera-a visualization system for exploratory research and analysis. J Comput Chem. (2004) 25:1605-12. doi: 10.1002/jcc.20084

27. Webb B, Sali A. Comparative protein structure modeling using MODELLER. Curr Protoc Protein Sci. (2016) 86:29. 1-37. doi: 10.1002/cpps.20

28. Studier FW. Protein production by auto-induction in high density shaking cultures. Protein Expr Purif. (2005) 41:207-34. doi: 10.1016/j.pep.2005.01.016

29. Schwarz H, Schmittner M, Duschl A, Horejs-Hoeck J. Residual endotoxin contaminations in recombinant proteins are sufficient to activate human CD1c+ dendritic cells. PLoS ONE. (2014) 9:e113840. doi: 10.1371/journal.pone.0113840

30. Schwarz H, Gornicec J, Neuper T, Parigiani MA, Wallner M, Duschl A, et al. Biological activity of masked endotoxin. Sci Rep. (2017) 7:44750. doi: $10.1038 /$ srep 44750

31. Case DA, Cerutti DS, Cheatham Iii TE, Darden TA, Duke RE, Giese TJ, et al. AMBER 2017. University of California, San Francisco, CA (2017).

32. Lindorff-Larsen K, Piana S, Palmo K, Maragakis P, Klepeis JL, Dror RO, et al. Improved side-chain torsion potentials for the Amber ff99SB protein force field. Proteins. (2010) 78:1950-8. doi: 10.1002/prot.22711

33. Jorgensen WL, Chandrasekhar J, Madura JD, Impey RW, Klein ML. Comparison of simple potential functions for simulating liquid water. J Chem Phys. (1983) 79:926-35. doi: 10.1063/1.445869

34. Wallnoefer HG, Handschuh S, Liedl KR, Fox T. Stabilizing of a globular protein by a highly complex water network: a molecular dynamics simulation study on factor xa. J Phys Chem B. (2010) 114:7405-12. doi: 10.1021/jp101654g

35. Pierce LCT, Salomon-Ferrer R, Augusto F, De Oliveira C, Mccammon JA, Walker RC. Routine access to millisecond time scale events with accelerated molecular dynamics. J Chem Theory Comput. (2012) 8:2997-3002. doi: $10.1021 /$ ct $300284 c$

36. Adelman SA, Doll JD. Generalized Langevin equation approach for atom/solid-surface scattering: general formulation for classical scattering off harmonic solids. J Chem Phys. (1976) 64:2375-88. doi: 10.1063/1.432526

37. Berendsen HJC, Postma JPM, Gunsteren WFV, Dinola A, Haak JR. Molecular dynamics with coupling to an external bath. J Chem Phys. (1984) 81:3684-90. doi: $10.1063 / 1.448118$

38. Ryckaert JP, Ciccotti G, Berendsen HJC. Numerical-integration of cartesian equations of motion of a system with constraints molecular-dynamics of N-alkanes. J Comput Phys. (1977) 23:327-41. doi: 10.1016/0021-9991(77)90098-5

39. Darden T, York D, Pedersen L. Particle mesh Ewald: An N.log(N) method for Ewald sums in large systems. J Chem Phys. (1993) 98:10089-92. doi: $10.1063 / 1.464397$

40. Miao Y, Sinko W, Pierce L, Bucher D, Walker RC, Mccammon JA. Improved reweighting of accelerated molecular dynamics simulations for free energy calculation. J Chem Theory Comput. (2014) 10:2677-89. doi: $10.1021 / \mathrm{ct} 500090 \mathrm{q}$

41. Roe DR, Cheatham TE. PTRAJ and CPPTRAJ: software for processing and analysis of molecular dynamics trajectory data. J Chem Theory Comput. (2013) 9:3084-95. doi: 10.1021/ct400341p
42. Kamenik AS, Kahler U, Fuchs JE, Liedl KR. Localization of millisecond dynamics: dihedral entropy from accelerated MD. J Chem Theory Comput. (2016) 12:3449-55. doi: 10.1021/acs.jctc.6b00231

43. Schrodinger Llc. The PyMOL Molecular Graphics System, Version 1.8.6.0 (2017).

44. Kay LE, Keifer P, Saarinen T. Pure absorption gradient enhanced heteronuclear single quantum correlation spectroscopy with improved sensitivity. J Am Chem Soc. (1992) 114:10663-5. doi: 10.1021/ja00052a088

45. Stewart PDS, Kolek SA, Briggs RA, Chayen NE, Baldock PFM. Random microseeding: a theoretical and practical exploration of seed stability and seeding techniques for successful protein crystallization. Crystal Growth Design. (2011) 11:3432-41. doi: 10.1021/cg2001442

46. Powell HR, Battye TGG, Kontogiannis L, Johnson O, Leslie AGW. Integrating macromolecular X-ray diffraction data with the graphical user interface iMosflm. Nat Protoc. (2017) 12:1310-25. doi: 10.1038/nprot.2017.037

47. Winn MD, Ballard CC, Cowtan KD, Dodson EJ, Emsley P, Evans PR, et al. Overview of the CCP4 suite and current developments. Acta Crystallogr D Biol Crystallogr. (2011) 67:235-42. doi: 10.1107/S0907444910045749

48. Emsley P, Lohkamp B, Scott WG, Cowtan K. Features and development of Coot. Acta Crystallogr D Biol Crystallogr. (2010) 66:486-501. doi: $10.1107 /$ S0907444910007493

49. Adams PD, Afonine PV, Bunkoczi G, Chen VB, Davis IW, Echols N, et al. PHENIX: a comprehensive Python-based system for macromolecular structure solution. Acta Crystallogr D Biol Crystallogr. (2010) 66:213-21. doi: 10.1107/S0907444909052925

50. Egger M, Jurets A, Wallner M, Briza P, Ruzek S, Hainzl S, et al. Assessing protein immunogenicity with a dendritic cell line-derived endolysosomal degradome. PLoS ONE. (2011) 6:e17278. doi: 10.1371/journal.pone.0017278

51. Korotchenko E, Moya R, Scheiblhofer S, Joubert IA, Horejs-Hoeck J, Hauser $\mathrm{M}$, et al. Laser facilitated epicutaneous immunotherapy with depigmented house dust mite extract alleviates allergic responses in a mouse model of allergic lung inflammation. Allergy. (2019) 75:1217-28. doi: 10.1111/all.14164

52. Kruisbeek AM. Production of mouse T cell hybridomas. Curr Protoc Immunol. (2001) Chapter 3:Unit 3.14. doi: 10.1002/0471142735.im0314s24

53. Martinez-Sanchez ME, Huerta L, Alvarez-Buylla ER, Villarreal Lujan C. Role of cytokine combinations on $\mathrm{CD} 4+\mathrm{T}$ cell differentiation, partial polarization, and plasticity: continuous network modeling approach. Front Physiol. (2018) 9:877. doi: $10.3389 /$ fphys.2018.00877

54. Tubo NJ, Jenkins MK. TCR signal quantity and quality in CD4(+) T cell differentiation. Trends Immunol. (2014) 35:591-6. doi: $10.1016 /$ j.it.2014.09.008

55. Machado Y, Freier R, Scheiblhofer S, Thalhamer T, Mayr M, Briza P, et al. Fold stability during endolysosomal acidification is a key factor for allergenicity and immunogenicity of the major birch pollen allergen. J Allergy Clin Immunol. (2016) 137:1525-34. doi: 10.1016/j.jaci.2015.09.026

56. Thai R, Moine G, Desmadril M, Servent D, Tarride JL, Menez A, et al. Antigen stability controls antigen presentation. J Biol Chem. (2004) 279:50257-66. doi: 10.1074/jbc.M405738200

57. Kim A, Hartman IZ, Poore B, Boronina T, Cole RN, Song N, et al. Divergent paths for the selection of immunodominant epitopes from distinct antigenic sources. Nat Commun. (2014) 5:5369. doi: 10.1038/ncomms6369

58. Eriksson AE, Baase WA, Zhang XJ, Heinz DW, Blaber M, Baldwin $\mathrm{EP}$, et al. Response of a protein structure to cavity-creating mutations and its relation to the hydrophobic effect. Science. (1992) 255:178-83. doi: $10.1126 /$ science. 1553543

59. Lee B. Estimation of the maximum change in stability of globular proteins upon mutation of a hydrophobic residue to another of smaller size. Protein Sci. (1993) 2:733-8. doi: 10.1002/pro.5560020505

60. Rashin AA. Aspects of protein energetics and dynamics. Prog Biophys Mol Biol. (1993) 60:73-200. doi: 10.1016/0079-6107(93)90017-E

61. Van Niel G, Wubbolts R, Stoorvogel W. Endosomal sorting of MHC class II determines antigen presentation by dendritic cells. Curr Opin Cell Biol. (2008) 20:437-44. doi: 10.1016/j.ceb.2008.05.011

62. Kamath SD, Scheiblhofer S, Johnson CM, Machado Y, Mclean T, Taki AC, et al. Effect of structural stability on endolysosomal degradation and T-cell reactivity of major shrimp allergen tropomyosin. Allergy. (2020). doi: $10.1111 /$ all.14410 
63. Sadegh-Nasseri S, Kim A. Exogenous antigens bind MHC class II first, and are processed by cathepsins later. Mol Immunol. (2015) 68:81-4. doi: 10.1016/j.molimm.2015.07.018

64. Sojikul P, Buehner N, Mason HS. A plant signal peptide-hepatitis B surface antigen fusion protein with enhanced stability and immunogenicity expressed in plant cells. Proc Natl Acad Sci USA. (2003) 100:2209-14. doi: $10.1073 /$ pnas. 0438037100

65. Wallner, M., Hauser, M., Himly, M., Zaborsky, N., Mutschlechner, S., Harrer, A., et al. Reshaping the Bet v 1 fold modulates $\mathrm{T}(\mathrm{H})$ polarization. J Allergy Clin Immunol. (2011) 127:1571-8 e9. doi: 10.1016/j.jaci.2011.01.064

66. So T, Ito HO, Koga T, Watanabe S, Ueda T, Imoto T. Depression of Tcell epitope generation by stabilizing hen lysozyme. J Biol Chem. (1997) 272:32136-40. doi: 10.1074/jbc.272.51.32136

67. Ohkuri $\mathrm{T}$, Nagatomo $\mathrm{S}$, Oda $\mathrm{K}$, So $\mathrm{T}$, Imoto $\mathrm{T}$, Ueda $\mathrm{T}$. A protein's conformational stability is an immunologically dominant factor: evidence that free-energy barriers for protein unfolding limit the immunogenicity of foreign proteins. J Immunol. (2010) 185:4199-205. doi: 10.4049/jimmunol.0902249

68. Mine Y, Zhang JW. Comparative studies on antigenicity and allergenicity of native and denatured egg white proteins. J Agric Food Chem. (2002) 50:2679-83. doi: 10.1021/jf0112264

69. So T, Ito H, Hirata M, Ueda T, Imoto T. Contribution of conformational stability of hen lysozyme to induction of type 2 T-helper immune responses. Immunology. (2001) 104:259-68. doi: 10.1046/j.1365-2567.2001. 01314.x

70. Corse E, Gottschalk RA, Allison JP. Strength of TCR-peptide/MHC interactions and in vivo $\mathrm{T}$ cell responses. J Immunol. (2011) 186:5039-45. doi: 10.4049/jimmunol.1003650

71. Goldsteins G, Persson H, Andersson K, Olofsson A, Dacklin I, Edvinsson A, et al. Exposure of cryptic epitopes on transthyretin only in amyloid and in amyloidogenic mutants. Proc Natl Acad Sci USA. (1999) 96:3108-13. doi: 10.1073/pnas.96.6.3108

72. Topalian SL, Gonzales MI, Ward Y, Wang X, Wang RF. Revelation of a cryptic major histocompatibility complex class II-restricted tumor epitope in a novel RNA-processing enzyme. Cancer Res. (2002) 62:5505-9.

73. Lanzavecchia A. How can cryptic epitopes trigger autoimmunity? J Exp Med. (1995) 181:1945-8. doi: 10.1084/jem.181.6.1945

74. Warnock MG, Goodacre JA. Cryptic T-cell epitopes and their role in the pathogenesis of autoimmune diseases. Br J Rheumatol. (1997) 36:1144-50. doi: 10.1093/rheumatology/36.11.1144

75. Winter P, Stubenvoll S, Scheiblhofer S, Joubert I, Strasser L, Briganser $\mathrm{C}$, et al. In silico design of $\mathrm{Phl} \mathrm{p} 6$ variants with altered folding stability significantly impacts antigen processing, immunogenicity and immune polarization. bioRxiv [Preprint]. (2020). doi: 10.1101/2020.02.26 967265

Conflict of Interest: The authors declare that the research was conducted in the absence of any commercial or financial relationships that could be construed as a potential conflict of interest.

Copyright (C) 2020 Winter, Stubenvoll, Scheiblhofer, Joubert, Strasser, Briganser, Soh, Hofer, Kamenik, Dietrich, Michelini, Laimer, Lackner, Horejs-Hoeck, Tollinger, Liedl, Brandstetter, Huber and Weiss. This is an open-access article distributed under the terms of the Creative Commons Attribution License (CC BY). The use, distribution or reproduction in other forums is permitted, provided the original author(s) and the copyright owner(s) are credited and that the original publication in this journal is cited, in accordance with accepted academic practice. No use, distribution or reproduction is permitted which does not comply with these terms. 